Marquette University

e-Publications@Marquette

$1-1-2005$

Early Determinants of Women in the IT Workforce: A Model of Girls' Career Choices

Monica Adya

Marquette University, monica.adya@marquette.edu

Kate Kaiser

Marquette University, kate.kaiser@marquette.edu

Accepted version. Information Technology \& People, Vol. 18, No. 3 (2005): 230-259. DOI. (C) Emerald 2005. Used with permission. 


\title{
Early Determinants of Women in the IT Workforce: A Model of Girls' Career Choices
}

\author{
Monica Adya \\ College of Business, Marquette University \\ Milwaukee, WI \\ Kate M. Kaiser \\ College of Business, Marquette University \\ Milwaukee, WI
}

\begin{abstract}
:
Purpose - To develop a testable model for girls' career choices in technology fields based on past research and hypotheses about the future of the information technology (IT) workforce.

Design/Methodology/Approach - Review and assimilation of literature from education, psychology, sociology, computer science, IT, and business in a model that identifies factors that can potentially influence a girl's choice towards or against IT careers. The factors are categorized into social factors (family, peers, and media), structural factors (computer use, teacher/counselor influence, same sex versus coeducational schools), and individual differences. The impact of culture on these various factors is also explored.
\end{abstract}

Findings - The model indicates that parents, particularly fathers, are the key influencers of girls' choice of IT careers. Teachers and counselors provide little or no career direction. Hypotheses propose that early access to computers may reduce intimidation with technology and that same-sex education may serve to reduce career bias against IT.

Research Limitations/Implications - While the model is multidisciplinary, much of research from which it draws is five to eight years

Information Technology \& People, Vol 18, No. 3 (2005): pg. 230-259. DOI. This article is @ Emerald and permission has been granted for this version to appear in e-Publications@Marquette. Emerald does not grant permission for this article to be further copied/distributed or hosted elsewhere without the express permission from Emerald. 
NOT THE PUBLISHED VERSION; this is the author's final, peer-reviewed manuscript. The published version may be accessed by following the link in the citation at the bottom of the page.

old. Patterns of career choices, availability of technology, increased independence of women and girls, offshore/nearshore outsourcings of IT jobs are just some of the factors that may be insufficiently addressed in this study.

Practical Implications - A "Recommendations" section provides some practical steps to increase the involvement of girls in IT-related careers and activities at an early age. The article identifies cultural research as a limitation and ways to address this.

Originality/value - The paper is an assimilation of literature from diverse fields and provides a testable model for research on gender and IT.

Keywords: Culture, Parents, Communication technologies, Gender, Careers

\section{Introduction}

The decline of the dot.com era and increased global outsourcing of IT jobs has retracted the promise of attractive employment in IT and may have filtered out inflated demand. Universities have experienced lower enrollment, particularly of women, in IT-related majors, contrary to the impact of women's movement, wherein more women are entering male- dominated fields. While women represent 46.6 percent of the US workforce, only about 35 percent of the US IT workforce is female (Information Technology Association of America, 2003). Between 1996 and 2002, the number of women in the US IT workforce declined from 41 percent to 34.9 percent (Information Technology Association of America, 2003). More disturbingly, women hold only 10 percent of the top IT positions in the United States and fewer women are rising up the IT leadership ladder than in the past (Gibson, 1997; D'Agostino, 2003). Such trends pervade globally despite statistics indicating that one half of internet users are women and that computer use by women has experienced a steady increase over the past decade (Friedman, 2000; Trauth et al., 2003).

IT, as a field, manifests itself diversely in the form of computer information systems (CIS), management information systems (MIS), and computer science (CS) degrees. Although a popular notion often emerging from CS and CIS is that IT is highly technical, behavioral issues and creativity in problem solving and design are critical success factors for IT professionals. The more diverse the IT workplace and the larger the pool of talent from which to draw, the more likely IT solutions will address a broad range of issues and the needs of a

Information Technology \& People, Vol 18, No. 3 (2005): pg. 230-259. DOI. This article is (C) Emerald and permission has been granted for this version to appear in e-Publications@Marquette. Emerald does not grant permission for this article to be further copied/distributed or hosted elsewhere without the express permission from Emerald. 
diverse end-user community (Florida and Gates, 2002). The IT profession is missing valuable human resources and women are bypassing rewarding career options. What circumstances lead women to an IT career and, just as importantly, what draws women away from it? While most published studies relate to college women and women in the IT workforce, career-oriented decisions are made much earlier, possibly at ages 11-17 (Barltrop, 1988; Marso and Pigge, 1994). By this age, although girls are not fully exposed to the longterm implications of their career choices, many have already decided against math, science, and technology (MST) (American Association of University Women, 1990, 1992, 1998a, 2000). Their course selections reflect their career orientation and can often block out MST careers.

Factors that influence decisions in early teens versus college and after are different. We examine early determinants of career choice for middle and high school students, particularly girls, focusing on factors that impact the critical years when adolescents can be encouraged to follow IT-related careers. We propose a model that assimilates literature from diverse fields such as math, science, engineering, education, and sociology and suggests that social, structural, and personal variables impact IT career choice (Ahuja, 2002; Beise et al., 2003; Trauth, 2002). Further, the paper examines whether these influences vary across ethnic cultures. We discuss how new technological and social trends may invalidate findings from past literature and suggest revised propositions in light of these new trends. We conclude with a broad research agenda addressing multiple levels of analysis and methodologies. The questions addressed are:

- What is the impact of social influences such as gender stereotypes, role models, peers, family, and media/culture on children's choices of IT as a career?

- What is the impact of structural variables such as teachers/counselors, school and personal technology resources, and same-sex education on children's choices of IT as a career?

- How do social and structural factors manifest across different ethnic cultures?

- How do individual differences impact children's choices of IT as a career?

Information Technology \& People, Vol 18, No. 3 (2005): pg. 230-259. DOI. This article is (C) Emerald and permission has been granted for this version to appear in e-Publications@Marquette. Emerald does not grant permission for this article to be further copied/distributed or hosted elsewhere without the express permission from Emerald. 
- How have social, structural, and individual differences e influenced children's IT career choices from the late 1990s, particularly in light of the challenges facing the US IT industry?

\section{Understanding Early Influences of Career Choice}

Much has been written in fields as diverse as sociology, education, psychology, math, and science about the genderization of careers. Few of these studies specifically relate to IT careers. Recently, studies have revealed a gender imbalance in IT (Ahuja, 2002; Beise et al., 2003; Camp, 1997; Trauth et al., 2003; von Hellens et al., 2000). Career genderization occurs early in an adolescent's life, possibly in middle school or the early years of high school. What influences girls' choices for or against IT? Drawing upon Ahuja's (2002) classification of social and structural influences on women's IT careers, the model of Beise et al. (2003) of women's career decisions, and individual factors suggested by Trauth (2002), this paper extends literature to children and adolescents with a focus on girls and sets a broad research agenda for IT-related career choices.

Ahuja (2002) provides an initial framework for classifying some early determinants of careers. That study examined factors that influenced women's entry and performance in IT careers and classified these factors into social and structural barriers. We posit that there are social and structural influences that can impact career choices positively or negatively, and we modify Ahuja's model for children. Social influences are biases that impact internal and external gender perceptions. Gender stereotyping, role models, peers, media, and parents are examples of social influences. Structural influences are manifested in the institutional support available such as teachers and counselors, access to technology, and same-sex versus coeducational schools. While both social and structural factors can influence decisions about career choice, early perceptions of children are most influenced by social factors such as parents, peers, and role models. Young adolescents are not exposed to structural factors to the same extent as women and men in professional settings.

When applied to skills, interests, and career options, stereotyping about gender roles can limit opportunities for both sexes and deprive the workforce of talent. While gender defines the essence of being male or female, gender roles carry expectations about how

Information Technology \& People, Vol 18, No. 3 (2005): pg. 230-259. DOI. This article is (C) Emerald and permission has been granted for this version to appear in e-Publications@Marquette. Emerald does not grant permission for this article to be further copied/distributed or hosted elsewhere without the express permission from Emerald. 
females and males should behave, feel, and think. Gender stereotyping can be inherent in the way a girl perceives her role in society based on subtle societal cues she has grown up with, but can also be influenced by social and structural entities such as parents, teachers, peers, and counselors. Although we classify gender stereotypes as a social variable, it has its roots in both social and structural factors. The same may be true of teachers who are assigned by schools and so are considered structural. On the other hand, a child's interaction with teachers can be social and teachers themselves undergo similar social construction, as do the children they teach. In such instances, social activity occurs within a structural setting. The model also considers individual differences and cultural impact. Inherent personality traits and manifestation of different external influences make children unique. Their individual differences draw their interests to activities and content areas such as problem solving, ability and willingness to interact with people. Finally, ethnic culture can strongly influence social and structural variables or at least emphasize differences for samples across several cultures.

The outcome variable of interest is career choice. Although two well-established theories, the Theory of Reasoned Action (Ajzen and Fischbein, 1980) and the Theory of Planned Behavior (Ajzen, 1985), make a convincing case for attitudes towards technology as an outcome variable, many intervening factors prevent a direct translation between attitudes towards technology and career choice. While many ITP 18,3 232 adolescents today have positive attitudes towards technology and find the computer and its applications "cool", this positive attitude does not manifest itself in career choice, as evidenced by declining enrolment at college-level IT programs. Furthermore, an adolescent's career choice will often be influenced by social, structural, and economic pressures that may have little to do with attitude towards technology. These various elements of the model and their interactions with each other are presented in Figure 1 and are discussed at length in the next few sections.

\section{Social Factors Influencing Career Choice}

\section{Role Models}

Career choices are often influenced by role models (National Academy of Sciences, 1997). Women in the workforce, however, have

Information Technology \& People, Vol 18, No. 3 (2005): pg. 230-259. DOI. This article is @ Emerald and permission has been granted for this version to appear in e-Publications@Marquette. Emerald does not grant permission for this article to be further copied/distributed or hosted elsewhere without the express permission from Emerald. 
a more difficult time finding role models and mentors to motivate their careers (Scandura and Ragins, 1993; Trauth et al., 2003). Teen role models are often societal figures that promote certain lifestyle, social image, and behaviors that have little impact in motivating career choices other than in music, sports, or movies. Not surprisingly, career choice role models are familial or educational (Dryler, 1998). Prior literature has not recognized this distinctive influence of role models from media versus from family and so separating the two was challenging (Clutterbuck and Ragins, 2002). The proposed model focuses on role models that directly influence academic and career choices.

\section{Family}

Family is one of the most influential contexts of socialization in childhood and adolescence (Dryler, 1998). While the impact of parental guidance is felt unequivocally in choice of traditional and nontraditional careers, it is most strongly observed in choice of nontraditional careers. Direct forms of parental influence, such as the degree to which students see their parents choosing IT careers or having contact with technology, are strong motivators to train for technical jobs (Breakwell et al., 1988; Dryler, 1998). Family members can also motivate career choices indirectly equally persuasively. For instance, a parent may not be an IT professional but may encourage girls to pursue or actively compete in careers perceived to be "masculine". These parents may still be acting as role models of perseverance and achievement without being IT professionals.

Jackson et al. (1993) suggest that women who enter maledominated fields such as science often come from families where mothers are working, both parents are highly educated, and success is considered critical. Mothers with four-year degrees are more likely to influence career choices than mothers without such qualifications (Smith, 2000). Although college- educated mothers influence both traditional and non-traditional career choices, women choosing nontraditional careers indicate that their fathers have a stronger, more direct bearing on careers choices in nontraditional environments such as MST (Gates, 2002; Trauth, 2002; Dryler, 1998; Leslie et al., 1998; Scandura and Ragins, 1993). One of the subjects interviewed in Trauth (2002, p. 106) reflects on the role of her father:

Information Technology \& People, Vol 18, No. 3 (2005): pg. 230-259. DOI. This article is (C) Emerald and permission has been granted for this version to appear in e-Publications@Marquette. Emerald does not grant permission for this article to be further copied/distributed or hosted elsewhere without the express permission from Emerald. 
If I didn't have my father who sat down, and you know, helped me choose the subjects, then I might have chosen the wrong subjects. I might have chosen the ones that I could get good grades in or that wouldn't have led to anything.

Turner et al. (2002) found that 73 percent of working women indicated their fathers as strongly influencing their career choice. However, children who are close to their parent of the same sex will often reflect career choices of that parent. Parents must recognize the child's persona in order to provide correct vocational guidance and have a positive impact on career choice. Unlike other factors discussed later, the literature is unequivocal regarding the positive influence of parents, particularly fathers, on career choices.

Siblings can have some influence on career choices. In particular for girls, older brothers can influence the entry of girls into traditionally "masculine" careers (Banks et al., 1995). On the other hand, girls who have only sisters tend to choose careers that are more traditionally "feminine". Similar sibling influence is found for boys with male siblings.

\section{Peer Group}

In the absence of mentors, peers may possibly influence careers (Kram and Isabella, 1985). However, in teenage years peers have more impact on social responsiveness, behaviors, fashion styles, and attitudes but little on career choices. During these adolescent and post- adolescent stages, peer influence, particularly of boys on girls, is often observed to impact female self-concept, self-efficacy, classroom experiences, and external goal orientation. Such changes are seen to cause a clear demarcation between boys' and girls' career choices despite the fact that girls still continue to score well on national level testing (Leslie et al., 1998). Findings that discuss teen peer influence on ITP 18,3 234 career choices are, at best, meager. Consequently, we extrapolate from findings at college and post-graduate level, where there is some mixed evidence of peer influence on career choices or computer use. Such peer influences were shown to have both positive and detrimental effects on career choices. Smith (2000) finds that male peers often play an important part in choice of MST as a career choice for some women. Brekke (1997), on the other hand, attributes

Information Technology \& People, Vol 18, No. 3 (2005): pg. 230-259. DOI. This article is (C) Emerald and permission has been granted for this version to appear in e-Publications@Marquette. Emerald does not grant permission for this article to be further copied/distributed or hosted elsewhere without the express permission from Emerald. 
NOT THE PUBLISHED VERSION; this is the author's final, peer-reviewed manuscript. The published version may be accessed by following the link in the citation at the bottom of the page.

lack of participation in college-level physics to partly result from peer pressure that steers students away from MST careers.

\section{Media}

Printed and electronic media influences and enhances gender stereotypes that focus largely on physical image rather than on motivating career choices. Although such images are often interpreted by girls as being unrealistic, they want to conform to these images in response to social and peer pressures (Milkie, 1999). Pictures in computer magazines and the representation of women in textbooks and software are few and usually presented stereotypically, serving to alienate women further from technology ( $\mathrm{Na}, 2001$; Culley, 1988). These representations are passive and do not depict women in positions of power or as active computer users (Brownell, 1992). For instance, analysis of television advertising reported 70 percent of males as central, authoritative roles and having more credibility regarding product knowledge (McArthur and Resco, 1975; Furnham and Voli, 1989). Women, on the other hand, are most often shown against the backdrop of children (Harris and Stobart, 1986; Na, 2001). Awareness of these media-generated biases has put pressure on the press to reduce the gender bias of commercials, but a comprehensive review covering Asia, Australia, Europe, North America, and South America indicates a persistent global problem with gender stereotypes projected on the powerful media of television commercials (Furnham and Mak, 1999; Signorielli et al., 1994). While trade journals and media popular among young and adult women have begun representing women in more professionally active roles, young teens do not focus there. Seventeen and Cosmo Girl, the two most popular teen magazines, have often been criticized for having content that does little by way of reducing gender stereotypes and more importantly, portraying women in professional, technological careers. Content analysis of these fashion and beauty magazines reveals a strong disinterest in career related issues. For instance, 30 percent of magazine space in Cosmopolitan is used for fashion and beauty, 23 percent for sex and relationships, and 34 percent for promotions with little left for discussing career alternatives (Nelson and Paek, 2003). This phenomenon is observed in global editions of Cosmopolitan in countries such as UK, India, China, Thailand, and Brazil. We expect similar gender stereotyping effects to exist in television media.

Information Technology \& People, Vol 18, No. 3 (2005): pg. 230-259. DOI. This article is (C) Emerald and permission has been granted for this version to appear in e-Publications@Marquette. Emerald does not grant permission for this article to be further copied/distributed or hosted elsewhere without the express permission from Emerald. 


\section{Gender Stereotypes}

Girls' perceptions of IT jobs may mirror stereotypes that do not represent the dynamic and rewarding nature of the field (von Hellens et al., 2000). The Rhode Island Economic Policy Council (2000) reported that teenagers considered IT "uncool, nerdy, or boring". Such perceptions threaten self-concept and career choices (Steele, 1997). For instance, math has been stereotyped as a masculine field and often is a critical filter that keeps women out of MST careers (Beise et al., 2003; Beyer et al., 2002; Eccles et al., 1990; Sherman, 1982). During math testing women experience a "unique psychological state" Women in the IT workforce 235 caused by stereotype threat and motivation to avoid confirming the stereotype leading to increased anxiety that can interfere with performance (Spencer et al., 1999). This is especially curious in countries such as Ireland where girls consistently score significantly higher than boys in the national junior certificate exams (ages 15-16) but the gap in math and science careers is inversely significant (Trauth, 2002).

Beliefs about the role-appropriate behavior of others, especially women, often restrict choice of careers in college despite there being no differences between men and women in career decision making styles (Harren et al., 1978). Up to age ten, girls have similar subject interests as boys and are perceived to be better at all or most subjects than boys. Francis (2000) finds in her evaluation of elementary school students in England that neither boys nor girls chose IT as their most favorite subject. As career choices form, students begin taking courses that reflect their choice of college education, narrowing their career options (Miller and Budd, 1999). Examining Scholastic Aptitude Test scores, Sadker and Sadker (1995) found that most girls decided to pursue social science careers rather than natural science. These decisions were lifetime decisions since the girls selected courses that eliminated the opportunity to pursue MST careers.

What causes these gender-biased perceptions of technology careers? While parents, teachers, and peers positively influence career choices, these role models also reinforce gender stereotypical career perceptions. Often role models carry hidden messages about boys' and girls' capacity to work with computers (Volman and van Eck, 2001). Children whose parents have higher levels of education tend to resist gender stereotyping while those whose parents have high school or

Information Technology \& People, Vol 18, No. 3 (2005): pg. 230-259. DOI. This article is @ Emerald and permission has been granted for this version to appear in e-Publications@Marquette. Emerald does not grant permission for this article to be further copied/distributed or hosted elsewhere without the express permission from Emerald. 
lower levels of education tend to conform to gender stereotypes (Bouchard and St-Amant, 2000). In the latter cases, children too, tend to conform to gender stereotypes. Where parental perceptions and girls' self-perceptions about their ability and success in mathematics tends to be stereotypical, performance can be negatively affected (Jacobs, 1991).

Teachers influence gender stereotyping of roles and choices through their interaction with students. Studies find that teachers often give students the impression that boys are inherently better at working with computers than girls (Sanders and Stone, 1986). Culley (1988) found that teachers in primary schools often considered boys to be more interested in computers and these teachers tended to enjoy teaching computer-related subjects to boys more than girls. Teachers in such situations often attribute certain expertise to boys and let them have priority over girls in computer use (Volman and van Eck, 2001). This often holds true for both male and female teachers. Possibly the enthusiasm of boys, their spontaneous questions and responses, and their overwhelming presence in computer labs discourages girls (Lipinsky et al., 1986; Lockheed, 1986).

\section{Structural Factors Influencing Career Choice}

Structural factors represent the institutional support available to women in pursuit of their careers. The role of teachers and counselors in exposing students to technology, access to computer technology both at home as well as in schools, and the nature of the school environment - same-sex or co-educational - are structural factors that can influence the genderization or neutralization of IT careers.

\section{Teacher/counselor}

Research findings lean towards the negative regarding the role of teachers and counselors on MST career choices. Dick and Rallis (1991) examined 2,000 high school students, finding that teachers had a strong influence on girls' choices of career in mathematics. Other empirical evidence has not been as encouraging. Teacher/counselor advising tends to reflect a gender bias when directing girls towards traditional careers and boys to non-traditional careers (Gates, 2002). Women in IT are most discouraged by teachers, guidance counselors, and male professors (Turner et al., 2002), although women who

Information Technology \& People, Vol 18, No. 3 (2005): pg. 230-259. DOI. This article is (C) Emerald and permission has been granted for this version to appear in e-Publications@Marquette. Emerald does not grant permission for this article to be further copied/distributed or hosted elsewhere without the express permission from Emerald. 
moved from non-IT to IT careers often indicated male professors to be a strong influence in that move (Canes and Rosen, 1995). Since most computer science and IT faculties are predominantly male, some students may have had few female professors in these courses.

At issue is also the fact that most full-time counselors devote a small percentage of their time on occupational and job counseling. The National Center for Education Statistics (NCES) found that career and occupational counseling ranked fifth out of eight functions typically performed by high school counselors (National Center for Education Statistics, 2003). Considering that only about 29 percent of girls receive support from career counselors, this directly impacts the amount of counseling provided to girls. Moreover, middle and high school teachers and counselors tend to feel comfortable advising in more traditional fields, possibly because they do not have sufficient IT backgrounds to be aware of its career paths (Freeman and Aspray, 1999). College level professors may have a broader perspective of IT career opportunities to better direct students. Students attaining a higher level of maturity by college are able to make choices based on a broader perspective of social and structural influences on their careers.

\section{Technology Access at School}

Women IT professionals cite school access to computers as the most prominent reason for their interest in an IT career (Turner et al., 2002). However, many children, particularly in low-income neighborhoods, may not have had this opportunity. While computer access in schools has increased significantly, reports on actual use of computers in school and gender differences in such use, have been mixed. Some studies report that gender differences in the use of computers at school are non-existent or declining (Doornekamp, 1993; Durndell and Thomson, 1997). Others report that boys use computers more frequently at school for a wider range of activities than girls (Comber et al., 1997; DuBois and Schubert, 1986; Huber and Schofield, 1998). Irrespective of these mixed message, the effects of differential computer access has long-term effects.

\section{Technology Access at Home}

The ownership and use of home computers has been divided along gender lines as well as economic lines. At home, boys use

Information Technology \& People, Vol 18, No. 3 (2005): pg. 230-259. DOI. This article is (C) Emerald and permission has been granted for this version to appear in e-Publications@Marquette. Emerald does not grant permission for this article to be further copied/distributed or hosted elsewhere without the express permission from Emerald. 
computers more frequently than girls and are more likely to own computers or be prominent users of shared computers (Colley et al., 1994; Doornekamp, 1993; Durndell et al., 1995; Harris, 1999). They tend to use computers more often than girls in one another's homes as a social activity (Durndell and Thomson, 1997). Even when young girls and boys play together using computers, girls can be less engrossed in the activity and may let boys continue playing by themselves. Boys demand more power and functionality from the technology used at home, often asking for better internet connectivity or more capable computer technology (Habib and Cornford, 2002). This effect snowballs to IT use in college, where students with home computers have a significantly more positive attitude towards IT in college (Selwyn, 1998).

User beliefs of perceived usefulness and attitudes about computers have been established as key determinants of IT usage intention and behaviors (Davis, 1989; Venkatesh and Brown, 2001; Venkatesh and Davis, 2000). While having access to computers is one step in familiarizing children with computers, the manner in which they use computers may influence beliefs and attitudes about technological careers. Although the gender gap in access to technology is nonexistent, use of computers and the internet is still divided along gender lines. For instance, boys use the internet for a wider range of activities such as games, shopping, and finding information about news, weather, and sports while girls tend to restrict internet use largely for e-mail and access to educational resources (National Center for Education Statistics, 2002). Girls prefer low-threat, high challenging activities as part of their education. However, any form of computer playfulness relates positively with computer competence, computer attitudes, and computer self-efficacy and is shown to reduce computer anxiety (Webster and Martocchio, 1992). Women exposed to more play and collaboration-based assignments in training are more likely to choose MST as careers (Smith, 2000).

Girls' use of computers and the internet for play has been limited by the shortage of relevant software games, and internet sites. Previously most games were geared for boys. Not until 1996 did Mattel offer "Barbie Fashion Designer" for girls to design clothing. The software game industry has responded only after noting young girls as a large lucrative target market. If the only contact girls have had with

Information Technology \& People, Vol 18, No. 3 (2005): pg. 230-259. DOI. This article is (C) Emerald and permission has been granted for this version to appear in e-Publications@Marquette. Emerald does not grant permission for this article to be further copied/distributed or hosted elsewhere without the express permission from Emerald. 
computers is in school, many do not realize the fun and enjoyment of using a computer. While online use appears to be similar for both boys and girls before age 12, girls' computers use drops as they get older. Media companies have only recently begun determining that girls have different preferences to boys, for example, creating versus killing, and collaboration versus competition (Gorriz and Medina, 2000). The assumption of the cyberspace as gender-free ignores that computers are used in a context. The hope of egalitarian use depends on the society in which girls and boys use computers.

\section{Same-sex versus Co-educational Schools}

Sex-segregated environments inadvertently reinforce gender stereotypes, squander opportunities to address issues of gender inequity, and expose students to teasing from peers in co-educational classes (Vezeau et al., 2000; Viadero, 2001). School environment has no impact on senior students from public school with regard to math (Vezeau et al., 2000). Students attending same-sex high schools have minimal pressures from the opposite sex and have a better sense of belonging (American Association of University Women, 1990, 1998b; Brutsaert and Van Houtte, 2002; Watson et al., 2002). If high school experiences reinforce notions that boys adapt more to technical areas, same-sex students are devoid of comparisons in the classroom (Jackson, 2002; Jones and Clarke, 1995). One might expect that student of same- sex schools would not as likely embrace genderspecific career choices. Another assumption is that parents of all-girl schools expect their daughters to excel in MST, and therefore, they have enrolled them in schools where gender discrimination exists minimally. Danziger, 1998 finds that ITP 18,3 238 intellectual development at same-sex schools is impressive and girls are well prepared for college education.

To understand and filter mixed messages regarding same-sex versus co-educational environments, researchers should examine the impact of these variables and outcomes on perceptions and careerchoices in the two school environments. While structural factors may exert the same influence in same-sex and co-educational schools, peer influence could have a differential impact on career choices at these two types of school.

Information Technology \& People, Vol 18, No. 3 (2005): pg. 230-259. DOI. This article is (C) Emerald and permission has been granted for this version to appear in e-Publications@Marquette. Emerald does not grant permission for this article to be further copied/distributed or hosted elsewhere without the express permission from Emerald. 
NOT THE PUBLISHED VERSION; this is the author's final, peer-reviewed manuscript. The published version may be accessed by following the link in the citation at the bottom of the page.

\section{Individual Differences}

A complex but fascinating emerging theory suggests that individual differences play an important role in forming career choices (Trauth et al., 2004). This theory challenges the essentialist (Venkatesh and Morris, 2000) and social construction (Adam, 2002; Adam et al., 2001) perspectives of gender and IT and explains individual responses of women, and their experience as girls, to the socio-cultural environment. Many individual differences are split along gender lines (Trusty et al., 2000). Personality traits, enjoyment of computers, and overall outlook are some characteristics that account for these differences. Evidence exists regarding how personality traits, classified as feminine or masculine, lead to occupational choice (Holland, 1997; Lyons, 1984; Oakes, 1990; Stevens and Macintosh, 2003). Women in IT reported several personality characteristics that made them the "odd girl out" - powerful, forthright, strong, ambitious, driven, mathematical, logical, and less social than other girls (Trauth, 2002, p. 110). Although female students enjoy using computers less than male students and perceive more problems with software, IT career women report higher levels of enjoyment with computers (Turner et al., 2002; Reinen and Plomp, 1997). Students with nontraditional majors have a more positive outlook on leadership and achievement and are more positively predisposed to computers than those on traditional career paths (Moore, 1983). While external experiences and societal expectations shape these characteristics, they impact occupational choices at young ages. Recognizing that impact of individual differences and personality characteristics on career choice is a complex construct and has only recently begun to gain attention, we introduce individual differences as a variable in our model and expect that future work will provide more insights on its role on career choices.

\section{Ethnic Culture}

The under representation of women in the IT workforce is a phenomenon that is observed worldwide, but the problem is larger in developed nations such as the USA, Australia, New Zealand, and Ireland (Trauth, 2000, 2002; Trauth et al., 2003, von Hellens and Nielsen, 2001; von Hellens et al., 2000). Trauth (2002) and von Hellens et al. (2001), however, find that women from India and China

Information Technology \& People, Vol 18, No. 3 (2005): pg. 230-259. DOI. This article is (C) Emerald and permission has been granted for this version to appear in e-Publications@Marquette. Emerald does not grant permission for this article to be further copied/distributed or hosted elsewhere without the express permission from Emerald. 
have more positive attitudes towards MST careers. While both India and China are similar in terms of economic environment, low representation of girls and women in education and population demands on resources, both represent a broad population that does well in careers related to MST. For instance, for 2001-2002 India's National Association of Software and Service Companies (2004) found that while currently the percentage of women in the Indian IT workforce is only 21 percent, it is projected to increase to 35 percent by the end of 2005 . The figures are even more impressive in ITenabled services, where the Women in the IT workforce 239 percentage of women in the workforce is 65 percent. These statistics are interesting in a country where per capita income is only about $\$ 90$, adoption of computers in homes and schools is slow, and only about 25 percent of the population in India is projected to have access to the internet in 2004. Yet, India's workforce, in general, is considered skilled enough to be one of the leading providers of IT outsourcing. Although market demands are clearly shaping such workforce trends, possibly, ethnic culture provides a more positive MST careerorientation to women in these countries (Trauth, 2002).

Women and girls are grossly underrepresented in schools and colleges in developing and low-income countries such as China and India, and consequently often lag behind boys in access to education (Alderman et al., 1996). World Bank figures from 1990 indicate that 78 girls of every 100 boys receive education in these countries and a much smaller percentage of these women ever reach college. For those that do, gender roadblocks may still exist. Not all girls take to full-time employment upon graduation. The ones that do face a myriad of social and ethnic factors that encourage or dissuade them from pursuing successful careers in non-traditional fields. We do not anticipate that these factors are any different from those faced by girls in the US. Nor do we anticipate that a different set of social and structural variables or individual differences apply to girls in India or China. What then makes the relative impact of these factors be differentially felt on girls in India and China compared to girls in the USA, Australia, or Ireland? Focusing on India, we speculate on how some constructs in our model may be impacted by the socio-economic culture of that country. In doing so, we assume a social location of urban, educated, middle class and upper middle class families, an assumption that is not unfounded since most of the growth in the

Information Technology \& People, Vol 18, No. 3 (2005): pg. 230-259. DOI. This article is (C) Emerald and permission has been granted for this version to appear in e-Publications@Marquette. Emerald does not grant permission for this article to be further copied/distributed or hosted elsewhere without the express permission from Emerald. 
Indian information society has occurred in corporate and upper middle classes. As Pal (2003) suggests, India gains its power from its vast middle class and it is the under-employed urban engineers who have good English language skills that have gained the most from the boom in India's IT sector.

While there is extensive gender stereotyping of social roles in India, stereotyping of careers is atypical from Western cultures. As a human resource consultant based in India suggests, "in the US, there is more resistance towards women and minorities and the pay discrimination is more obvious. In India, such things hardly exist" (Baishya, 2004). Careers are classified not as masculine or feminine but rather prestigious or not, and MST careers are considered "respectable". From early school years, children, in general, are encouraged, if not expected, to excel in MST. Parental and family expectations play a significant role in choice of careers and they expect girls and boys equally to take on careers that relate to either the medical profession or engineering. Such behavior has been observed in many parents irrespective of parental educational qualifications or choice of occupation. A child's successful entry into one of these careers becomes a matter of prestige since most medical and engineering schools are extremely selective in admissions and often, students must try multiple times to obtain admission. This nongenderization of education follows through into schools. Teachers have conformed to their teaching role and consequently, most career advising comes from parents. Indian education system sets up career path choices at the end of high school. Once the path is chosen, changes are difficult to implement. There is also an expectation that all education must be completed at a certain age and it is unusual to see a college student beyond the age of 23 to 24 years. With these constraints, poor performance in math or science makes careers in medicine or engineering inaccessible. Teachers and parents often will consider such low-grade performance as an individual limitation that can be overcome with hard work and discipline.

Individual differences may well be similar across ethnic cultures. Every culture will have a representation of women who are determined, self-confident, and capable of taking on non- traditional careers. In an environment where girls are constantly encouraged to take technical and challenging careers, girls can be raised with the 
belief that they can take on any careers. There is little intimidation about taking MST subjects. Attitudes towards computers are not different between boys and girls due to the relatively late onset of computer technology in India. Computer technology has only begun to be pervasive in Indian homes and schools since 1996- 7 onwards. This delayed growth has been in parallel with the growth in access to and use of the internet. People often purchase computers for homes in order to get access to the internet. In the USA, internet applications, particularly e-mail and instant messaging, have increased girls' involvement with computers and have served to reduce the gender digital divide of the late 1990s. Such a digital divide has only existed minimally in India due to the parallel growth in computer and internet use, and has minimized gender differences in computer attitudes.

Two rapidly changing aspects of the Indian culture are peer influence and the role of media. Indian media do not differ from Western media with respect to portraying women in traditional passive roles of mother, daughter, grandmother, and wife. Where women are portrayed in active roles, these are not in the role of a working woman, much less someone who works directly with technology, but rather as someone who assists others such as her children. A new trend that has emerged since the early 1990s has been the significant emphasis on the physical image of girls, further distorting the stereotyped image of women. As the country's socio-economic status and quality of life improves, girls and women have the resources to conform to the image messages from media. The nature of peer influence may also change as a result of these media influences, possibly putting into play gender stereotyping of girls at a younger age. Much of our discussion above has been contextual and broad. With little literature to support our claims, we identify cultural differences as something that needs significant research momentum.

\section{Discussion of the Model}

The discussion above identified several factors that potentially influence early career choices. Table I summarizes relevant literature. The model suggests that perceived career choice is directly influenced by role models, gender stereotypes, availability of technological resources, gender-separated education, and individual differences and that career role models primarily emerge from family - mothers, fathers, and siblings - and, to a lesser degree, from among peers, 
teachers, and counselors. These same influencers, however, may reinforce gender stereotypes that discourage girls from pursuing MST careers. Such gender stereotypes may pervade printed and electronic media. Teachers and counselors may positively impact career choices if they are active technology users and understand IT careers. Samesex schools may either allay gender stereotypes or further deepen them. Access to technological resources can come from home and school and impact attitudes about computer usefulness and feelings of intimidation. While other sources for access such as libraries exist, most access comes from homes or schools.

Finally, ethnic culture serves as an umbrella over social and structural factors. It impacts girls' relationships with their parents, peers, counselors, and teachers. Media often reinforces the beliefs of a culture and reinforces attitudes and perceptions. Similarly, access to and use of computers at home and school is differential in its bearing on career choices. The model is exploratory and while our summary of the literature provides some suggestions regarding the nature of these relationships, we expect that empirical validations of this model, particularly against the backdrop of multiple cultures and school environments, will reveal the true relationships.

\section{Changing Times}

Research over the past three decades may not reflect the how IT has pervaded homes and schools. Home computer use is now equally divided between male and female users: 41 million men and 39.7 million women in 1995 to 68 million men and 70 million women in 2001 (National Center for Education Statistics, 2002). Computer training is integrated in kindergarten to high school (K-12) curriculum. Computers used for instruction in US public schools rose from 5.6 million in 1995 to over 10 million in 2001 (National Center for Education Statistics, 2000). As represented in Figure 2, the percentage of public schools accessing the internet rose from 50 percent to 99 percent in the same time (National Center for Education Statistics, 2001).

Social influences of fathers and peers as role models should remain stable over the next generation of college students. The change may come from the impact of mothers on girls' career choices as more women achieve higher levels of education and join the

Information Technology \& People, Vol 18, No. 3 (2005): pg. 230-259. DOI. This article is (C) Emerald and permission has been granted for this version to appear in e-Publications@Marquette. Emerald does not grant permission for this article to be further copied/distributed or hosted elsewhere without the express permission from Emerald. 
workforce. This increased presence of women in the workforce as well as in leadership positions in male- dominated fields should reduce the effect of gender stereotyping and male peers, and in turn, related careers. While the assumption here is that of an intact family structure of one male and one female parent, the results may manifest differently for children raised in single-parent or same-sex parent families.

$P 1$. Fathers will continue to exert a positive influence on their daughters' choices of technology careers.

P2. More girls will cite their mothers as role models in their choice of technological careers.

P3. Male peers will have no significant influence on girls' choices of technological careers.

The influence of teachers and counselors will likely not change over the next generation. Despite the pervasiveness of computers and internet usage in the K-12 system, surveys by the National Center for Education Statistics (2000) indicate that only about 60 percent of teachers reported using computers for instruction and only 41 percent gave assignments requiring computers. Only 23 percent of teachers felt prepared for using computers and the internet in teaching. Teachers who report being technologically prepared are more likely to use technology in class and assign materials that requiring computer use for problem solving and data analysis (National Center for Education Statistics, 2000). Moreover, the current generation of teachers and counselors, while more knowledgeable about computer use for personal productivity, may not still be aware of the wide range of IT career choices.

P4. Teachers and counselors will continue to steer girls towards traditional career choices.

The influence of the media will likely not differ over the next generation of students. While most professional and trade journals have begun to more evenly represent women in professional settings, most middle and high school students prefer to read popular magazines such as Seventeen and Cosmopolitan. Popular television channels such as MTV only serve to perpetuate these gender

Information Technology \& People, Vol 18, No. 3 (2005): pg. 230-259. DOI. This article is (C) Emerald and permission has been granted for this version to appear in e-Publications@Marquette. Emerald does not grant permission for this article to be further copied/distributed or hosted elsewhere without the express permission from Emerald. 
stereotypes (Signorielli et al., 1994). These continue to focus largely on messages relating to fashion and superstars.

P5. The media will continue to perpetuate stereotypes that will be detrimental to the choices of girls' technology-related careers.

Increased accessibility to computers in home and school, integration of technology in K- 12 curricula, the popularity of internet gaming and instant messaging are trends that reduce the difference between the time that boys and girls spend with computers. While the nature of their computer use still differs significantly, time spent with computers reduces the intimidation effect of technology on some individuals.

P6. Increased access to technological resources in home and at school will have a positive influence on girls' choices of technology careers.

Offshore software development has changed the landscape of some countries to emphasize IT more than they used to. The tight labor market in the USA and some European nations has caused India and China to provide offshore outsourcing. Western Europe, for instance, is projected to face a shortage of IT professionals by 1.7 million by 2005 (West and Bogumil, 2001). India's emphasis on excellence and a rich system of educational institutions has encouraged unprecedented growth in software (West and Bogumil, 2001). Such market changes make IT a more viable career than ever before, which in turn affects families' work habits, education, and interactions.

P6. Girls in countries experiencing increased IT exporting will be more inclined to select an IT career than those girls in those countries where IT industry is facing challenges from offshore outsourcing.

\section{Propoposed Research Agenda}

The proposed model calls for multiple levels of analysis and level-appropriate methods to better understand how social, structural, and individual factors influence career choices. Using longitudinal observations and cross-cultural comparisons where possible, research in this area can be conducted at three levels:

Information Technology \& People, Vol 18, No. 3 (2005): pg. 230-259. DOI. This article is (C) Emerald and permission has been granted for this version to appear in e-Publications@Marquette. Emerald does not grant permission for this article to be further copied/distributed or hosted elsewhere without the express permission from Emerald. 
NOT THE PUBLISHED VERSION; this is the author's final, peer-reviewed manuscript. The published version may be accessed by following the link in the citation at the bottom of the page.

(1) the individual child and nuclear family level;

(2) school and district level; and

(3) the macro-level, where population trends and behaviors are examined.

Research at the individual and nuclear family level as well as school districts will extend to same-sex and co-educational schools and to comparisons among urban, suburban, and rural schools. The model can also be tested in its entirety using survey-based methods with middle and high school children, their families and peers. Several instruments tested with adults are adaptable to adolescent populations. The following sections discuss how researchers can operationalize the proposed constructs.

\section{Family Influence}

Our research assessment strongly indicates that parental education and choice of careers are strong motivators for children's career choices as well. We expect these two items to be key measures of the family influence construct, as Dryler (1998) has suggested in her study of the Swedish education system. We suggest using items that measure parental influence on choice of major or career because there may be non-working parents who may influence career choices. An assessment of the adolescent's relationship may be important in order to determine whether the relationship between parents and the child is strong enough for parents to motivate career choices. Tang (2002) suggests items that assess an adolescent's independence or dependence from parents which can be adapted to career choices. In this context, one could measure a child's perception of their parents as role models. Researchers must also recognize that career influencers in the family may be siblings or other relatives.

\section{Peer Influence}

Most operationalizations of peer influence relate to drug use and other similar negative behaviors. However, these studies have much to contribute in terms of assessing peer influence factors. For instance, Jang (2002) suggests that studies must measure actual behaviors of peers rather than perceived behaviors. To that extent, items can be designed to measure whether male and female peers have chosen IT

Information Technology \& People, Vol 18, No. 3 (2005): pg. 230-259. DOI. This article is (C) Emerald and permission has been granted for this version to appear in e-Publications@Marquette. Emerald does not grant permission for this article to be further copied/distributed or hosted elsewhere without the express permission from Emerald. 
careers, whether peers actually encouraged the choice of technology careers, whether a particular peer is considered a role model, and whether peer advice is more valuable than family advice. We suggest the inclusion of one perception measure - the perception of geekiness or nerdiness when an adolescent has made a technology career choice.

\section{Media}

The key assessment in this section is the choice of key media that students view or read. Researchers should identify popular media for adolescents and build these into the survey and interview questions. For instance, one could evaluate subjects about the extent to which the media they access provides valuable career advice and the exposure of women as active users of technology in these media. Such questions may indirectly reveal the gender stereotyping influence of media on girls and boys. Questions related to role models from media can be included in this construct as well.

\section{Access to Technology at Home and School}

Access to technology should measure some of the following aspects:

- presence of computers in home and schools;

- hours spent on computers at home and in school;

- the nature of usage at home and at school;

- teacher use of technology at home; and

- parental and sibling use of technology at home.

Norris et al. (2000) provide an instrument measuring teachers' home access to technology. Items from this construct can easily be adapted to the child and family's home computer use. Brecker (2000) provides similar measure of technology usage and access at home. The National Center for Education Statistics (2003) contributes survey items that specifically assess children's use of computers.

\section{Teacher/counselor Influence}

Research indicates that students do not adequately utilize teacher and counselor time for career advice and that teachers and counselors

Information Technology \& People, Vol 18, No. 3 (2005): pg. 230-259. DOI. This article is (C) Emerald and permission has been granted for this version to appear in e-Publications@Marquette. Emerald does not grant permission for this article to be further copied/distributed or hosted elsewhere without the express permission from Emerald. 
may not have sufficient knowledge about technology careers (Freeman and Aspray, 1999). We suggest these two to be key measures in this construct. The extent to which teachers and counselors have influenced career choice and stereotype certain professions are also important measures. Children's perceptions of teachers as role models will provide additional insight.

\section{Individual Differences}

The least mature construct - and the most malleable due to its nature and scope - is individual differences. These differences range from socio-economic status to perceptions about technology, personality preferences, and use of technology to name a few. Of immediate interest to us are three aspects of this construct:

(1) personality differences;

(2) perceptions of general self-efficacy; and

(3) attitudes towards computers.

Trauth (2002) suggests several personality traits that women IT professionals believe make them distinct:

- strong and driven;

- logical;

- less social; and

- aggressive.

Many personality measures, such as the Myers-Briggs Type Indicator (MBTI) (Myers and McCaulley, 1985), the Kolb Learning Style inventory (KLSI) (Kolb, 1984), and the Big Five Factors (Digman, 1990) can assess personality characteristics. Self-efficacy measures by Judge et al. (1998) can be used to determine perceptions of general self-efficacy. Researchers can adapt many computer attitude questionnaires, such as those by Lee (1970), Rafaeli (1986), Dambrot et al. (1985), Nickell and Pinto (1986), and Popovich et al. (1987). Table II provides a sample of constructs for research about the perception of IT by youth.

Using survey-based methods with adolescents poses certain challenges. Children may respond to surveys in a socially desirable 
manner and may experience interpretation bias based on their experiences. Surveys will not capture rich social cues that are more visible in face-to- face settings. On the other hand, individual interviews could intimidate some 10-14 year olds. We therefore recommend the use of small focus group interviews to understand student experiences. Such interviews, when conducted with peers, can provide rich insights into peer influence on career choices as well. Francis (2000) used semi-structured interviews and observations to understand subject preferences for 14-16 year olds. Trauth (2000) and Trauth et al. (2003) have relied on semi-structured interviews of women IT professionals. These techniques can be used for longitudinal observations of families to understand the progressive impact of social, cultural, and economic changes on career choices. Habib and Cornford (2002) successfully used interviews with adolescents and families to understand computer usage behaviors. They closely followed home computer usage of seven families over two years, describing their progression into gender domestication around the computer.

Possibly the most challenging construct to measure in this model is gender stereotyping. Survey-based methods may elicit socially desirable responses from parents and teachers. Items measuring this aspect would need to be carefully designed in order to minimize self-report bias. The blatancy of some of these questions may, however, be masked in small group settings, but the researcher must be careful that her questions do not lead the respondents. Multiple methods may need to be combined to obtain an objective assessment of this construct.

Access to children creates two challenges:

- obtaining parental and administrative approval for student access; and

- getting student and parental commitment to participate over time.

Parental consent may be more easily obtained once the school administration has approved participation. Even then, middle school children are often involved in extracurricular activities that may limit participation. Participation during school hours will be construed as distracting both by parents and school officials.

Information Technology \& People, Vol 18, No. 3 (2005): pg. 230-259. DOI. This article is (C) Emerald and permission has been granted for this version to appear in e-Publications@Marquette. Emerald does not grant permission for this article to be further copied/distributed or hosted elsewhere without the express permission from Emerald. 
NOT THE PUBLISHED VERSION; this is the author's final, peer-reviewed manuscript. The published version may be accessed by following the link in the citation at the bottom of the page.

\section{School and District Level Research}

Structural factors can best be examined using school and district level data. Access to and use of computers in the home and school can be obtained from students using small group interviews and observations and from teachers using survey, interviews, and observation. Brecker (2000) provides a survey instrument, Teaching, Learning and Computing (TLC), that examines instructional use of computers in schools, particularly the extent to which teachers use computer and laboratory facilities. Norris et al. (2000), on the other hand, measure teachers' home access to technology. Items from Rosenberg (1965) can be adapted to assess teacher self-esteem with regards to computers. Francis (2000) provides survey items to evaluate teacher attitudes towards use of computers. Self-reporting bias and social desirability issues suggest that survey or interviewbased techniques be complemented with observation about technology use, comfort with technology, and counseling/guidance behavior. For instance, Webb et al. (1997) used observation to examine how teachers grouped students during science instruction. The prevalence of technology resources and professional development of teachers and counselors depends on schools' resources advising a sample of different types of schools such as urban, suburban, rural, and private, reflecting varied socio-economic levels as well as in sex-segregated and co-educational institutions.

\section{Macro-level Research}

Secondary sources such as government and professional organizations can provide data at the macro level about IT career and market trends such as children's and households' computer and internet usage from the National Center for Education Statistics in the USA and from NASSCOM in India. Other sources include the World Bank, the International Monetary Fund (IMF), and National Statistics, which provides online UK statistics. Macro level data combined with school and district level data can extract meaningful relationships, such as in Dryler (1998), where data gathered by the Swedish Governmental Commission on Education Inequality and was used and matched with school-level data about parents to understand how parents as role models affect educational choice.

Information Technology \& People, Vol 18, No. 3 (2005): pg. 230-259. DOI. This article is (C) Emerald and permission has been granted for this version to appear in e-Publications@Marquette. Emerald does not grant permission for this article to be further copied/distributed or hosted elsewhere without the express permission from Emerald. 
National level data can help examine cultural comparisons of structural factors and social influences. Hanson et al. (1996) conducted a comparison of seven countries regarding gender stratification in science using data gathered by the Second International Math Study (SIMS) and Second International Science Study (SISS). Global sources such as the World Bank and the IMF will often be able to provide comparative multi-country data.

\section{Longitudinal Assessment}

Research conducted at multiple points in an adolescent's life span - middle school, high school, and early college - can provide a robust assessment of career influences. Although career choices begin forming towards the end of middle school and early high school, social and structural influences that shape these choices must be understood earlier. Research begun in fourth or fifth grade will capture early formative factors. The same students can be tracked periodically. Recognizing that years of exposure to college resources, a wider set of peers and professors can change career orientation, there may be value in testing this model on college students as well. Freshmen students, just out of high school, will closely represent the adolescent thinking that shaped their college course selections. The proposed model could be tested each year of their college education to determine if college experiences have brought about any career choice changes, the nature of those changes, and factors that have influenced them.

\section{Cross-cultural Comparison}

The model's value lies in its transferability to multiple cultures. Although language may be a potential barrier, in many countries most urban middle class adolescents and young adults have a working knowledge of English. Where language barriers do exist, measures must undergo rigorous translation and testing, first from English to the native language and then from the native language back to English. Karahanna et al. (2004) indicate that language translation is only one issue in cross-cultural research. Conceptual, construct, item, and scalar equivalence must be achieved before an instrument can be tested across cultures. This involves the identification of potential sources of bias both in the instrument as well as the measurement methods. Findings from a cross-cultural context can illustrate cultural

Information Technology \& People, Vol 18, No. 3 (2005): pg. 230-259. DOI. This article is (C) Emerald and permission has been granted for this version to appear in e-Publications@Marquette. Emerald does not grant permission for this article to be further copied/distributed or hosted elsewhere without the express permission from Emerald. 
change across nations. Insights from such findings can be used to make small, consequential changes to social and structural environments. Researchers will need to apply the same research techniques across cultures customizing language and ethnic idiosyncrasies. Care must be taken that methods are appropriate to flush out cultural differences (Srite et al., 2003).

\section{Implications for Stakeholders}

The research addresses IT workforce issues with regard to recruitment and retention. IT educators and policymakers can play a role in establishing environments conducive to technological careers. The misperception of what IT professionals do and what skills they need to succeed can deter many college students from choosing an ITrelated major, and therefore a career in that field. Some of the problem may be marketing what IT professionals do and what skills help them perform quality project management and software development. School district administrators can establish policies and allocate resources that support ongoing technological training of their teachers and counselors.

Before teachers can provide gender-neutral counseling, they need training to understand technology themselves as well as the career options provided by IT. Such training must begin at the licensing stages. Teachers report that they do not have adequate access to computers, adequate release time for technology training, as well as lack of good self-instructional software (National Center for Education Statistics, 2000). Such infrastructural support is critical in training veteran teachers who tend to use computers less often than those with less experience. Over 93 percent of teachers report that their main source of technological training is independent learning or support from colleagues. $\mathrm{K}-12$ systems need to provide an environment where teachers can become comfortable with their technology preparedness and convey enthusiasm about it to students. Administrators can build incentives for merit into evaluations. The onus for teachers is to be able to provide equal access to computers; create an environment for computer use that is non-competitive, non-threatening, and engages children in social interaction; supply software that appeals to girls as well as boys; and provide students with female models of competent computer use (McNair et al., 2001). Teacher awareness of IT career

Information Technology \& People, Vol 18, No. 3 (2005): pg. 230-259. DOI. This article is (C) Emerald and permission has been granted for this version to appear in e-Publications@Marquette. Emerald does not grant permission for this article to be further copied/distributed or hosted elsewhere without the express permission from Emerald. 
opportunities can help convey this information and encouragement adequately to students. Schools can provide opportunities for teachers and counselors to interact with industry to obtain better insights into IT careers. Careers fairs and internship opportunities should be actively encouraged in middle and high school children and these students should be encouraged to actively evaluate the impact of their career choices.

Parental involvement clearly has a positive bearing on choice of IT as a career. While educated mothers have a strong bearing on general career direction and are more consistently and deeply involved in academic lives of their children, fathers may have greater influence in choice of computing careers. As more mothers enter the workforce and earn higher levels of education, the positive impact of parental involvement continues to motivate daughters. School involvement through parent-teacher organizations, school board positions, and curriculum review are other outlets.

The technological outlook today is changing, and this change is optimistic. The awareness of pre-teen and teen girls as a viable software game market holds some promise for engaging girls in technology as long as the messages do not reinforce the traditional roles. Other media may influence girls indirectly. For example, Crime Scene Investigation (CSI) is presently one of the most popular television shows in the United States and may or may not have a strong teen audience. The two versions of the show have several nonnerdy women who spend significant time behind a microscope and discussing chemistry in addition to human behavior.

This research has extended prior work that has largely relied on examining college students and women in the IT workforce to schoolchildren. It is widely believed that social and structural factors shape adolescents' career choices. Our model provides specific factors within a socio-cultural context that can potentially explain adolescents' perceptions of IT careers. If we can successfully identify and manage student perceptions of IT careers at a young age, women may be better represented in the IT workforce and enrollments in IT programs may increase. Empirical research on our proposed model will serve to understand career influences and propose policy changes that may serve to increase the enrollment of women in MST careers.

Information Technology \& People, Vol 18, No. 3 (2005): pg. 230-259. DOI. This article is (C) Emerald and permission has been granted for this version to appear in e-Publications@Marquette. Emerald does not grant permission for this article to be further copied/distributed or hosted elsewhere without the express permission from Emerald. 
NOT THE PUBLISHED VERSION; this is the author's final, peer-reviewed manuscript. The published version may be accessed by following the link in the citation at the bottom of the page.

\section{References}

Adam, A. (2002), "Exploring the gender question in critical information systems", Journal of Information Technology, Vol. 17 No. 2, pp. 59-67.

Adam, A., Howcroft, D. and Richardson, H. (2001), "Absent friends? The gender dimension in IS research", in Russo, N.L., Fitzgerald, B. and DeGross, J.I. (Eds), Realigning Research and Practice in IS Development, Kluwer Academic, Boston, MA, pp. 333-52.

Ahuja, M.K. (2002), "Women in the information technology profession: a literature review, synthesis, and research agenda", European Journal of Information Systems, Vol. 11 No. 1, pp. 20-34.

Ajzen, I. (1985), "From intentions to actions: a theory of planned behavior", in Kuhl, J. and Beckman, J. (Eds), Action-Control: From Cognition to Behavior, Springer, Heidelberg, pp. 11-39.

Ajzen, I. and Fishbein, M. (1980), Understanding Attitudes and Predicting Social Behavior, Prentice-Hall, Englewood Cliffs, NJ.

Alderman, H., Behrman, J.R., Ross, D.R. and Sabot, R. (1996), "Decomposing the gender gap in cognitive skills in a poor rural economy", The Journal of Human Resources, Vol. 31 No. 1, pp. 226-54.

American Association of University Women (1990), Shortchanging Girls, Shortchanging America: Full Data Report, American Association of University Women, Washington, DC.

American Association of University Women (1992), The AAUW Report: How Schools Shortchange Girls, American Association of University Women, Washington, DC.

American Association of University Women (1998a), Gender Gaps: Where Schools Still Fail Our Children, American Association of University Women, Washington, DC.

American Association of University Women (1998b), Separated by Sex - A Critical Look at Single-Sex Education for Girls, American Association of University Women, Washington, DC.

American Association of University Women (2000), Tech-Savvy: Educating Girls in the New Computer Age, American Association of University Women, Washington, DC.

Baishya, D. (2004), "India Inc's hottest geeks are women", Economic Times, June 25 , available at:

Information Technology \& People, Vol 18, No. 3 (2005): pg. 230-259. DOI. This article is (C) Emerald and permission has been granted for this version to appear in e-Publications@Marquette. Emerald does not grant permission for this article to be further copied/distributed or hosted elsewhere without the express permission from Emerald. 
NOT THE PUBLISHED VERSION; this is the author's final, peer-reviewed manuscript. The published version may be accessed by following the link in the citation at the bottom of the page.

http://economictimes.indiatimes.com/articleshow/753129.cms (accessed September 30, 2004).

Banks, M., Bates, I., Breakwell, G., Bynner, J., Emler, N., Jameson, L. and Roberts, K. (1995), Careers and Identities, University Press, Philadelphia, PA.

Barltrop, J. (1988), "From school to work: choosing and planning a career", report of the Mount Druitt Longitudinal Study, School of Education, Macquarie University, North Ryde.

Beyer, S., Rynes, K., Perrault, J., Hay, K. and Haller, S. (2002), "Gender differences in computer science students", Association for Computing Machinery SIGCSE Technical Symposium on Computer Science Education, Cincinnati, OH, pp. 49-53.

Beise, C., Myers, M., VanBrackle, L. and Chevli-Saroq, N. (2003), "An examination of age, race, and sex as predictors of success in the first programming course", Journal of Informatics Education Research, Vol. 5 No. 1, pp. 51-64.

Breakwell, G.M., Fife-Schaw, C. and Devereux, J. (1988), "Parental influence and teenagers' motivation to train for technological jobs", Journal of Occupational Psychology, Vol. 61 No. 1, pp. 79-89.

Bouchard, P. and St-Amant, J.C. (2000), "Gender identities and school success", Alberta Journal of Educational Research, Vol. 46 No. 3, pp. 280-4

Brecker, H.J. (2000), "Access to computers in school", Communications of the ACM, Vol. 43 No. 6, pp. 24-5.

Brekke, S.E. (1997), "Physics classes, career choices, and inner-city schools", The Physics Teacher, Vol. 35 No. 8, p. 512.

Brutsaert, H. and Van Houtte, M. (2002), "Girls' and boys' sense of belonging in single-sex versus co-educational schools", Research in Education, No. 68 , pp. $48-56$.

Brock, D.B. and Sulsky, L.M. (1994), "Attitudes towards computers: construct validation and relations to computer use", Journal of Organizational Behavior, Vol. 15 No. 1, pp. 17-35.

Brownell, G. (1992), "The representation of females in computer education text for grades K-12", Journal of Computing in Childhood Education, Vol. 3 No. 1, pp. 43-54.

Camp, T. (1997), "The incredible shrinking pipeline", Communications of the ACM, Vol. 40 No. 10, pp. 103-10.

Information Technology \& People, Vol 18, No. 3 (2005): pg. 230-259. DOI. This article is (C) Emerald and permission has been granted for this version to appear in e-Publications@Marquette. Emerald does not grant permission for this article to be further copied/distributed or hosted elsewhere without the express permission from Emerald. 
NOT THE PUBLISHED VERSION; this is the author's final, peer-reviewed manuscript. The published version may be accessed by following the link in the citation at the bottom of the page.

Canes, B.J. and Rosen, H.S. (1995), "Following in her footsteps? Faculty gender composition and women's choices of college majors", Industrial \& Labor Relations Review, Vol. 48 No. 3, pp. 486-505.

Clutterbuck, D. and Ragins, B.R. (2002), Mentoring and Diversity: An International Perspective, Butterworth-Heinemann, Oxford.

Colley, A.M., Gale, M.T. and Harris, T.A. (1994), "Effects of gender role identity and experience on computer attitude components", Journal of Educational Computing Research, Vol. 10 No. 2, pp. 129-37.

Comber, C., Colley, A.M. and Hargreaves, D.J. (1997), "The effects of age, gender and computer experience upon computer attitudes", Educational Research, Vol. 39 No. 2, pp. 123-33.

Culley, L. (1988), "Option choice and careers guidance: gender and computing in secondary schools", British Journal of Guidance and Counseling, Vol. 16 No. 1, pp. 73-82.

D'Agostino, D. (2003), "Where are all the women IT leaders?", CIO Insight, October 1, available at: www.eweek.com/article2/0,1759,1309599,00.asp (accessed September 30, 2004).

Dambrot, F., Watkins-Malek, M.A., Silling, S., Marshall, R. and Garver, J. (1985), "Correlates of sex differences in differences in attitudes toward and involvement with computers", Journal of Vocational Behavior, Vol. 27 No. 1, pp. 71-86.

Danziger, C. (1998), "The trade-offs of a single-sex school: a parent's quandary", Independent School, Vol. 57 No. 2, p. 73.

Davis, F.D. (1989), "Perceived usefulness, perceived ease of use, and user acceptance of information technology", MIS Quarterly, Vol. 13 No. 3, pp. 319-40.

Dick, T.P. and Rallis, S.F. (1991), "Factors and influences on high school students' career choices", Journal for Research in Mathematics Education., Vol. 22 No. 4, pp. 281-92.

Digman, J.M. (1990), "Personality structure: emergence of the five-factor model", Annual Review of Psychology, Vol. 41 No. 1, pp. 417-40.

Doornekamp, B.G. (1993), "Students' valuation of the use of computers in education", Computers in Education, Vol. 21 Nos 1/2, pp. 103-13.

Dryler, H. (1998), "Parental role models, gender, and educational choice", British Journal of Sociology, Vol. 49 No. 3, pp. 375-98.

Information Technology \& People, Vol 18, No. 3 (2005): pg. 230-259. DOI. This article is (C) Emerald and permission has been granted for this version to appear in e-Publications@Marquette. Emerald does not grant permission for this article to be further copied/distributed or hosted elsewhere without the express permission from Emerald. 
NOT THE PUBLISHED VERSION; this is the author's final, peer-reviewed manuscript. The published version may be accessed by following the link in the citation at the bottom of the page.

DuBois, P.A. and Schubert, J.G. (1986), "Do your school policies provide equal access to computers? Are you sure?", Educational Leadership, Vol. 46 No. 6, p. 41.

Durndell, A. and Thomson, K. (1997), "Gender and computing: a decade of change?", Computers and Education, Vol. 28 No. 1, pp. 1-9.

Durndell, A., Glissov, P. and Siann, S. (1995), "Gender and computing: persisting differences", Educational Research, Vol. 37 No. 3, pp. 21927.

Eccles, J., Jacobs, J. and Harold, R. (1990), "Gender role stereotypes, expectancy effects, and parents' socialization of gender differences", Journal of Social Issues, Vol. 46 No. 2, pp. 183-201.

Freeman, P. and Aspray, W. (1999), "The supply of information technology workers in the United States", Computing Research Association, Washington, DC, available at: www.cra.org/ reports/wits/cra.wits.html (accessed September 30, 2004).

Friedman, M. (2000), "Women take to internet while avoiding IT", Computing Canada, Vol. 26 No. 18, p. 9.

Florida, R. and Gates, G. (2002), "Technology and tolerance: the importance of diversity of high technology growth", Survey Series, The Brookings Institution, Washington, DC, pp. 1-12, available at: www.brook.edu/dybdocroot/es/urban/techtol.pdf (accessed September $30,2004)$.

Francis, B. (2000), "The gendered subjects: students' subject preferences and discussions of gender and subject ability", Oxford Review of Education, Vol. 26 No. 1, pp. 35-48.

Furnham, A. and Farragher, E. (2000), "A cross-cultural content analysis of sex-role stereotyping in television advertisements: a comparison between Great Britain and New Zealand", Journal of Broadcasting \& Electronic Media, Vol. 44 No. 3, pp. 415-37.

Furnham, A. and Mak, T. (1999), "Sex role stereotyping in television commercials: a review and comparison of twelve studies done on five continents", Sex Roles, Vol. 41 Nos 5/6, pp. 413-37.

Furnham, A. and Voli, V. (1989), "Gender stereotypes in Italian television advertisements", Journal of Broadcasting and Electronic Media, Vol. 33 No. 2, pp. 175-85.

Information Technology \& People, Vol 18, No. 3 (2005): pg. 230-259. DOI. This article is (C) Emerald and permission has been granted for this version to appear in e-Publications@Marquette. Emerald does not grant permission for this article to be further copied/distributed or hosted elsewhere without the express permission from Emerald. 
NOT THE PUBLISHED VERSION; this is the author's final, peer-reviewed manuscript. The published version may be accessed by following the link in the citation at the bottom of the page.

Gates, J. (2002), "Women's career influences in traditional and non-traditional fields", poster presented at the Biennial Meeting of the Society for Research in Adolescence, New Orleans, LA.

Gattiker, U.E. and Hlavka, A. (1992), "Computer attitudes and learning performance: issues for management organization and training", Journal of Organizational Behavior, Vol. 13 No. 1, pp. 89-101.

Gibson, S. (1997), "The non-issue - gender in the IT field", PC Week, Vol. 14, p. 112.

Gorriz, C. and Medina, C. (2000), "Engaging girls with computers through software games", Communications of the ACM, Vol. 43 No. 1, pp. 429.

Habib, L. and Cornford, T. (2002), "Computers in the home: domestication and gender", Information Technology and People, Vol. 15 No. 2, pp. 159-74.

Hanson, S.L., Schaub, M. and Parker, D.P. (1996), "Gender stratification in the science pipeline: a comparative analysis of seven countries", Gender and Society, Vol. 10 No. 3, pp. 271- 90.

Harren, V.A., Kass, R.A., Tinsley, H.E.A. and Moreland, J.R. (1978), "Influence of sex role attitudes and cognitive styles on career decision making", Journal of Counseling Psychology, Vol. 25 No. 5, pp. 390-8.

Harris, P.R. and Stobart, J. (1986), "Sex role stereotyping in British television advertisements at different times of the day: an extension and refinement of Manstead and McCullough (1981)", British Journal of Social Psychology, Vol. 25 No. 2, pp. 155-64.

Harris, S. (1999), "Secondary school students' use of computers at home", British Journal of Educational Technology, Vol. 30 No. 40, pp. 331-9.

Holland, J.L. (1997), Making Vocational Choices, Psychological Assessment Resources, Inc., Odessa, FL.

Huber, B.R. and Schofield, J.W. (1998), "Gender and the sociocultural context of computing in Costa Rica", in Bromley, H. and Apple, M.W. (Eds), Education/Technology/Power: Educational Computing as a Social Practice, State University of New York Press, Albany, NY, pp. 103-32.

Information Technology Association of America (2003), "ITAA report of the Blue Ribbon Panel on IT Diversity", Information Technology Association of America, Arlington, VA, available at: www.itaa.org/workforce/docs/03divreport.pdf (accessed September $30,2004)$.

Information Technology \& People, Vol 18, No. 3 (2005): pg. 230-259. DOI. This article is (C) Emerald and permission has been granted for this version to appear in e-Publications@Marquette. Emerald does not grant permission for this article to be further copied/distributed or hosted elsewhere without the express permission from Emerald. 
NOT THE PUBLISHED VERSION; this is the author's final, peer-reviewed manuscript. The published version may be accessed by following the link in the citation at the bottom of the page.

Jackson, C. (2002), "Can single-sex classes in co-educational schools enhance the learning experiences of girls and/or boys? An exploration of pupils' perceptions", British Journal of Educational Research, Vol. 28 No. 1, pp. 37-48.

Jackson, L.A., Gardner, P.D. and Sullivan, L.A. (1993), "Engineering persistence: past, present, and future factors and gender differences", Higher Education, Vol. 26, pp. 227-46.

Jacobs, J.E. (1991), "Influence of gender stereotypes on parent and child mathematics attitudes", Journal of Educational Psychology, Vol. 83 No. 4, pp. 518-27.

Jang, S.J. (2002), "The effect of families, peers, schools, and attitudes on adolescents' drug use: do they vary with age?", Justice Quarterly, Vol. 19 No. 1, pp. 97-126.

Jones, S. (2003), "Let the games begin: gaming technology and internet among college students", Pew Internet and American Life Project, available at: www.pewinternet.org/pdfs/PIP_College_Gaming_Reporta.pdf (accessed September 30, 2004).

Jones, T. and Clarke, V.A. (1995), "Diversity as a determinant of attitudes: a possible explanation of the apparent advantage of single-sex settings", Journal of Educational Computing Research, Vol. 12 No. 1, pp. 51-64.

Judge, T.A., Locke, E.A., Durham, C.C. and Kluger, A.N. (1998), "Dispositional effects on job and life satisfaction: the role of core evaluations", Journal of Applied Psychology, Vol. 83 No. 1, pp. 17-34.

Kane, R.D. and Frazee, P. (1978), Occupational Choice: Do Traditional and Non-traditional Women Differ?, report, R.J. Associates, Inc., Arlington, VA.

Karahanna, E., Evaristo, R. and Srite, M. (2004), "Methodological issues in MIS cross-cultural issues", in Tan, F.B. (Ed.), Advanced Topics in Global Information Management, IDEA Group Publishing, Hershey, PA.

Kolb, D.A. (1984), Experiential Learning: Experience as the Source of Learning and Development, Prentice-Hall, Englewood Cliffs, NJ.

Kram, K.E. and Isabella, L.A. (1985), "Mentoring alternatives: the role of peer relationships in career development", Academy of Management Journal, Vol. 28 No. 1, pp. 110-32.

Lee, R.S. (1970), "Social attitudes and the computer revolution", Public Opinion Quarterly, Vol. 34 No. 1, pp. 53-9.

Information Technology \& People, Vol 18, No. 3 (2005): pg. 230-259. DOI. This article is (C) Emerald and permission has been granted for this version to appear in e-Publications@Marquette. Emerald does not grant permission for this article to be further copied/distributed or hosted elsewhere without the express permission from Emerald. 
NOT THE PUBLISHED VERSION; this is the author's final, peer-reviewed manuscript. The published version may be accessed by following the link in the citation at the bottom of the page.

Leslie, L.L., McCLure, G.T. and Oaxaca, R.L. (1998), "Women and minorities in science and engineering: a life sequence analysis", The Journal of Higher Education, Vol. 69 No. 3, pp. 239-76.

Lipinsky, J., Nida, R., Shade, D. and Watson, J. (1986), "The effects of microcomputers on young children: an examination of free-play choices, sex differences, and social interactions", Journal of Educational Computing Research, Vol. 2 No. 4, pp. 147-68.

Lockheed, M. (1986), Determinants of Student Computer Use: An Analysis from 1984 National Assessment of Educational Progress, Educational Testing Service, Princeton, NJ.

Lyons, M. (1984), "The DP psyche", Datamation, Vol. 30 No. 9, pp. 103-10.

McArthur, L.Z. and Resco, B.G. (1975), "The portrayal of men and women in American television commercials", Journal of Social Psychology, Vol. 97, pp. 209-20.

McNair, S., Kirova-Petrova, A. and Bhargava, A. (2001), "Computers and young children in the classroom: strategies for minimizing gender bias", Early Childhood Education Journal, Vol. 29 No. 1, pp. 51-5.

Marso, R.N. and Pigge, F.L. (1994), "Personal and family characteristics associated with reasons given by teacher candidates for becoming teachers in the 1990s: implications for the recruitment of teachers", paper presented at the Annual Conference of the Midwestern Educational Research Association, Chicago, IL.

Milkie, M.A. (1999), "Social comparisons, reflected appraisals, and mass media: the impact of pervasive beauty images on black and white girls' self-concept", Social Psychology Quarterly, Vol. 62 No. 2, pp. 190-210.

Miller, L. and Budd, J. (1999), "The development of occupational sex-role stereotypes, occupational preferences, and academic subject preferences in children at ages 8, 12, and 16", Educational Psychology, Vol. 19 No. 1, pp. 17-35.

Moore, B. (1983), "Factors that influence the career choices of rural minority students", Research Bulletin No. 31, South Carolina State College, Orangeburg, SC.

Myers, I.B. and McCaulley, M.H. (1985), Manual: A Guide to the Development and Use of the Myers-Briggs Type Indicator, Consulting Psychologists Press, Palo Alto, CA.

Information Technology \& People, Vol 18, No. 3 (2005): pg. 230-259. DOI. This article is @ Emerald and permission has been granted for this version to appear in e-Publications@Marquette. Emerald does not grant permission for this article to be further copied/distributed or hosted elsewhere without the express permission from Emerald. 
NOT THE PUBLISHED VERSION; this is the author's final, peer-reviewed manuscript. The published version may be accessed by following the link in the citation at the bottom of the page.

$\mathrm{Na}, \mathrm{M}$. (2001), "The cultural construction of the computer as a masculine technology: an analysis of computer advertisements in Korea", Asian Journal of Women's Studies, Vol. 7 No. 3, pp. 93-114.

National Academy of Sciences (1997), Adviser, Teacher, Role Model, Friend: On Being a Mentor to Students in Science and Engineering, National Academy Press, Washington, DC.

National Association of Software and Service Companies (2004), "Knowledge professionals", available at: www.nasscom.org/artdisplay.asp?cat_id 1/4 303 (accessed September 30, 2004).

National Center for Education Statistics (2000), Teachers Tools for The 21st Century: A Report on Teacher's Use of Technology, Education Public Center (ED Pubs), Jessup, MD.

National Center for Education Statistics (2001), Teacher Use of Computers and Internet in Public Schools, Education Public Center (ED Pubs), Jessup, MD.

National Center for Education Statistics (2002), "Digest of Education Statistics, 2002", National Center for Education Statistics, Washington, DC, available at: http://nces.ed.gov/programs/digest/d02/index.asp (accessed September 30, 2004).

National Center for Education Statistics (2003), High School Guidance Counseling, Education Public Center (ED Pubs), Jessup, MD, available at: www.nces.ed.gov/pubsearch/pubsinfo.asp?pubid=2003015 (accessed September 30, 2004).

Nelson, M.R. and Paek, H.J. (2003), "Exporting the 'fun, fearless female': Cosmopolitan magazine as a case study of a global media brand", poster presented at the Association for Education in Journalism and Mass Communication Annual Convention, Kansas City, MO.

Nickell, G. and Pinto, J. (1986), "The computer attitudes scale", Computers in Human Behavior, Vol. 2 No. 2, pp. 301-6.

Norris, C., Topp, N. and Soloway, E. (2000), "Access to computers at home", Communications of the ACM, Vol. 43 No. 6, pp. 25-6.

Oakes, J. (1990), Lost Talent: The Underparticipation of Women, Minorities, and Disabled Persons in Science, RAND Corporation, Santa Monica, CA.

Pal, J. (2003), "The developmental promise of information and communications technology in India", Contemporary South Asia, Vol. 12 No. 1, pp. 103-19.

Information Technology \& People, Vol 18, No. 3 (2005): pg. 230-259. DOI. This article is (C) Emerald and permission has been granted for this version to appear in e-Publications@Marquette. Emerald does not grant permission for this article to be further copied/distributed or hosted elsewhere without the express permission from Emerald 
NOT THE PUBLISHED VERSION; this is the author's final, peer-reviewed manuscript. The published version may be accessed by following the link in the citation at the bottom of the page.

Popovich, P.M., Hyde, K.R., Zakrajsek, T. and Blumer, C. (1987), "The development of the attitudes toward computer usage scale", Educational and Psychological Measurement, Vol. 47 No. 2, pp. 261-9.

Rafaeli, A. (1986), "Employee attitudes towards working with computers", Journal of Occupational Behavior, Vol. 7 No. 1, pp. 89-106.

Reinen, I.J. and Plomp, T. (1997), "Information technology and gender equality: a contradiction in terminis?", Computers and Education, Vol. 28 No. 2, pp. 65-78.

Rhode Island Economic Policy Council (2000), "What Rhode Island teens think of information technology careers", available at: www.ripolicy.org/resources/content/FocusGrpTeens.pdf (accessed September 30, 2004).

Rosenberg, M. (1965), Society and the Adolescent Self-Image, Princeton University Press, Princeton, NJ.

Sadker, M. and Sadker, D. (1995), Failing at Fairness: How our Schools Cheat Girls, Touchstone Books, New York, NY.

Sanders, J.S. and Stone, A. (1986), The Neuter Computer: Computers for Girls and Boys, Neal- Schuman Publishers, New York, NY.

Scandura, T.A. and Ragins, B.R. (1993), "The effects of gender and role orientation on mentorship in male-dominated occupations", Journal of Vocational Behavior, Vol. 43 No. 3, pp. 251-65.

Selwyn, N. (1998), "The effect of using a home computer on students" educational use of IT", Computers and Education, Vol. 31 No. 2, pp. 211-27.

Sherman, J.A. (1982), "Mathematics the critical filter: a look at some residues", Psychology of Women Quarterly, Vol. 6 No. 4, pp. 428-44.

Signorielli, N., McLeod, D. and Healy, E. (1994), "Gender stereotypes in MTV commercials: the beat goes on", Journal of Broadcasting \& Electronic Media, Vol. 38 No. 1, pp. 91-102.

Smith, L.B. (2000), "The socialization of females with regard to a technologyrelated career: recommendation for change", Meridian: A Middle School Computer Technologies Journal, Vol. 3 No. 2, available at: www.ncsu.edu/meridian/sum2000/career/index.html (accessed September 30, 2004).

Spencer, S.J., Steele, C.M. and Quinn, D. (1999), "Stereotype threat and women's math performance", Journal of Experimental Social Psychology, Vol. 35 No. 1, pp. 4-28.

Information Technology \& People, Vol 18, No. 3 (2005): pg. 230-259. DOI. This article is (C) Emerald and permission has been granted for this version to appear in e-Publications@Marquette. Emerald does not grant permission for this article to be further copied/distributed or hosted elsewhere without the express permission from Emerald. 
Srite, M., Straub, D., Loch, K., Evaristo, R. and Karahanna, E. (2003), "Inquiry into definitions of culture in IT studies", in Tan, F.B. (Ed.), Advanced Topics in Global Information Management, Idea Group Publishing, Hershey, PA.

Steele, M. (1997), "Using music to increase interest in computers for girls and minorities", Teaching and Change, Vol. 4 No. 4, pp. 293-312.

Stevens, C.D. and Macintosh, G. (2003), "Personality and attractiveness of activities within sales jobs", Journal of Personal Selling and Sales Management, Vol. 23 No. 1, pp. 23-37.

Tang, M. (2002), "A comparison of Asian America, Caucasian American, and Chinese college students: an initial report", Journal of Multicultural Counseling and Development, Vol. 30 No. 2, pp. 124-35.

Trauth, E. (2000), The Culture of an Information Economy: Influences and Impacts in The Republic of Ireland, Kluwer Academic, Boston, MA.

Trauth, E. (2002), "Odd girl out: an individual differences perspective on women in the IT profession", Information Technology and People, Vol. 15 No. 2, pp. 98-118.

Trauth, E.M., Nielsen, S.H. and von Hellens, L.A. (2003), "Explaining the IT gender gap: Australian stories for the new millennium", Journal of Research and Practice in Information Technology, Vol. 35 No. 1, pp. 720.

Trauth, E.M., Quesenberry, J.L. and Morgan, A.J. (2004), "Understanding the underepresentation of women in IT: toward a theory of individual differences", in Weisband, S. (Ed.), Proceedings of the 2004 ACM SIG MIS CPR Conference, Association for Computing Machinery, Tucson, AZ.

Trusty, J., Robinson, C.R., Plata, M. and Ng, K. (2000), "Effects of gender, socioeconomic status, and early academic performance on postsecondary educational choice", Journal of Counseling and Development, Vol. 78 No. 4, pp. 463-72.

Turner, S.V., Brent, P.W. and Pecora, N. (2002), Why Women Choose Information Technology Careers: Educational, Social, and Familial Influences, Annual Educational Research Association, New Orleans, LA.

Venkatesh, V. and Brown, S.A. (2001), "A longitudinal investigation of personal computers in homes: adoption determinants and emerging challenges", MIS Quarterly, Vol. 25 No. 1, pp. 71-102.

Information Technology \& People, Vol 18, No. 3 (2005): pg. 230-259. DOI. This article is (C) Emerald and permission has been granted for this version to appear in e-Publications@Marquette. Emerald does not grant permission for this article to be further copied/distributed or hosted elsewhere without the express permission from Emerald. 
NOT THE PUBLISHED VERSION; this is the author's final, peer-reviewed manuscript. The published version may be accessed by following the link in the citation at the bottom of the page.

Venkatesh, V. and Davis, F.D. (2000), "A theoretical extension of the technology acceptance model: four longitudinal field studies", Management Science, Vol. 46 No. 2, pp. 186-204.

Venkatesh, V. and Morris, M.G. (2000), "Why don't men ever stop to ask for directions? Gender, social influence, and their role in technology acceptance and usage behavior", MIS Quarterly, Vol. 24 No. 1, pp. $115-40$

Vezeau, C., Bouffard, T. and Chouinard, R. (2000), "The impact of single-sex versus coeducational school environment on girls' general attitudes, self-perceptions and performance in mathematics", Journal of Research and Development in Education, Vol. 34 No. 1, pp. 49-59.

Viadero, D. (2001), "Study cites flaws in single-sex public schools", Education Week, Vol. 20 No. 38, available at: www.edweek.com/ew/ewstory.cfm?slug=38gender.h20 (accessed October 7, 2004).

Volman, M. and van Eck, E. (2001), "Gender equity and information technology in education: the second decade", Review of Educational Research, Vol. 17 No. 4, pp. 613-34.

von Hellens, L.A. and Nielsen, S.H. (2001), "Australian women in IT", Communications of the ACM, Vol. 44 No. 7, pp. 46-52.

von Hellens, L.A., Nielsen, S.H. and Trauth, E.M. (2001), "Breaking and entering the male domain: women in the IT industry", in Serva, M. (Ed.), Proceedings of ACM SIGCPR Special Interest Group on Computer Personnel Research, Association for Computing Machinery, San Diego, CA, pp. 116-20.

von Hellens, L.A., Pringle, R., Nielsen, S.H. and Greenhill, A. (2000), "People, business, and IT skills: the perspective of women in the IT industry", in Nance, W. (Ed.), Proceedings of the ACM SIGCPR Special Interest Group on Computer Personnel Research, Association for Computing Machinery, Chicago, IL, pp. 152-7.

Watson, C.M., Quatman, T. and Eder, E. (2002), "Career aspirations of adolescent girls: effects of achievement level, grade, and single-sex school environment", Sex Roles, Vol. 46 Nos 9/10, pp. 323-35.

Webb, N.M., Baxter, G.P. and Thompson, L. (1997), "Teachers' grouping practices in fifth grade science classrooms", The Elementary School Journal, Vol. 98 No. 2, pp. 91-113.

Information Technology \& People, Vol 18, No. 3 (2005): pg. 230-259. DOI. This article is (C) Emerald and permission has been granted for this version to appear in e-Publications@Marquette. Emerald does not grant permission for this article to be further copied/distributed or hosted elsewhere without the express permission from Emerald. 
NOT THE PUBLISHED VERSION; this is the author's final, peer-reviewed manuscript. The published version may be accessed by following the link in the citation at the bottom of the page.

Webster, J. and Martocchio, J.J. (1992), "Microcomputer playfulness: development of a measure with workplace implications", MIS Quarterly, Vol. 16 No. 2, pp. 201-26.

West, L.A. and Bogumil, W.A. (2001), "Immigration and the global IT workforce", Communications of the ACM, Vol. 44 No. 7, pp. 21-5.

\section{Appendix}

Figure 1: Factors Influencing Girls' Career Choices

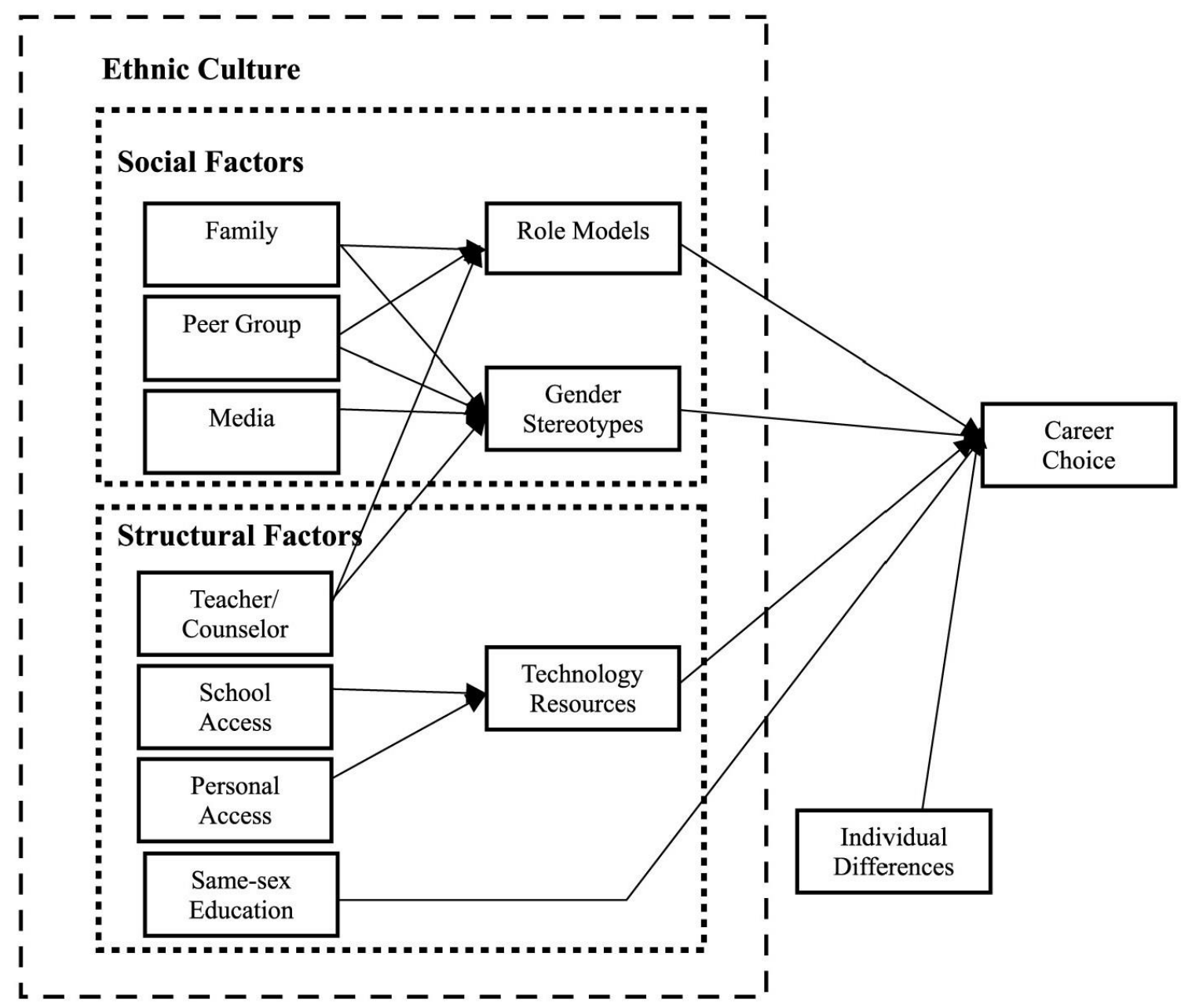

Information Technology \& People, Vol 18, No. 3 (2005): pg. 230-259. DOI. This article is (C) Emerald and permission has been granted for this version to appear in e-Publications@Marquette. Emerald does not grant permission for this article to be further copied/distributed or hosted elsewhere without the express permission from Emerald. 
NOT THE PUBLISHED VERSION; this is the author's final, peer-reviewed manuscript. The published version may be accessed by following the link in the citation at the bottom of the page.

Figure 2: Percentage of All Public Schools and Instructional Rooms Having Internet Access, Fall 1994 to Fall 2001

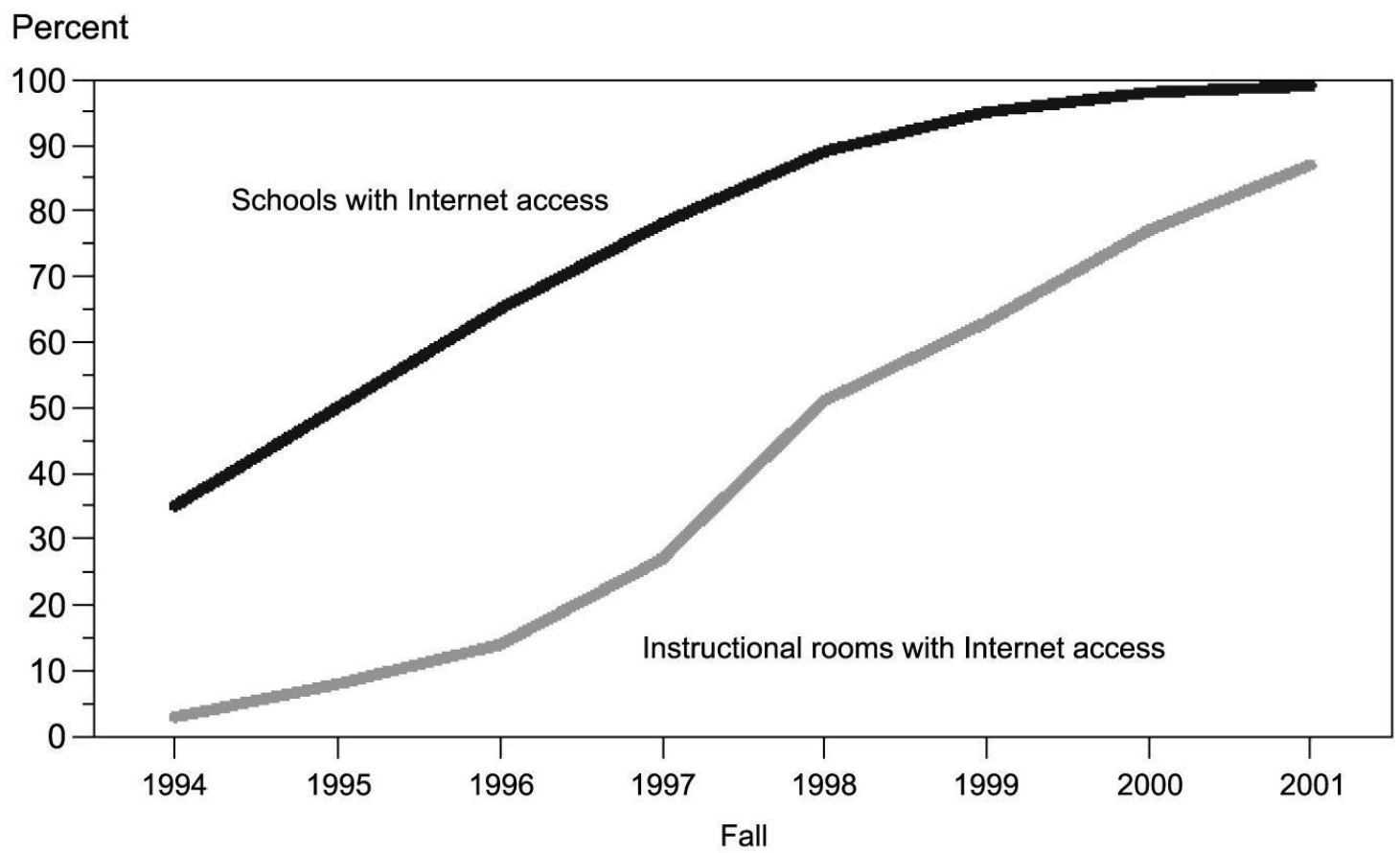

Information Technology \& People, Vol 18, No. 3 (2005): pg. 230-259. DOI. This article is (C) Emerald and permission has been granted for this version to appear in e-Publications@Marquette. Emerald does not grant permission for this article to be further copied/distributed or hosted elsewhere without the express permission from Emerald. 
Table I. Summary of research related to girls' career choices

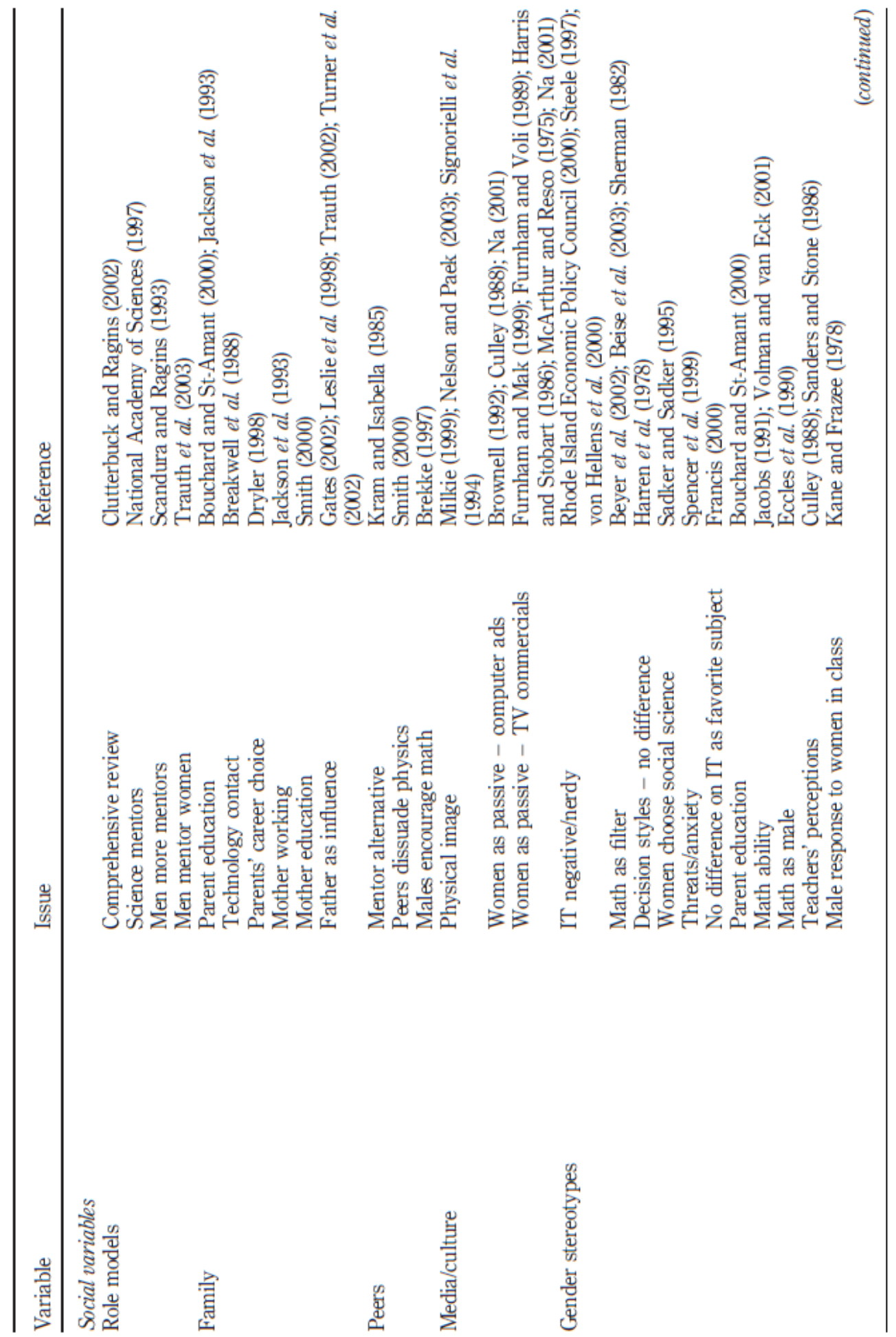

Information Technology \& People, Vol 18, No. 3 (2005): pg. 230-259. DOI. This article is (C) Emerald and permission has been granted for this version to appear in e-Publications@Marquette. Emerald does not grant permission for this article to be further copied/distributed or hosted elsewhere without the express permission from Emerald. 


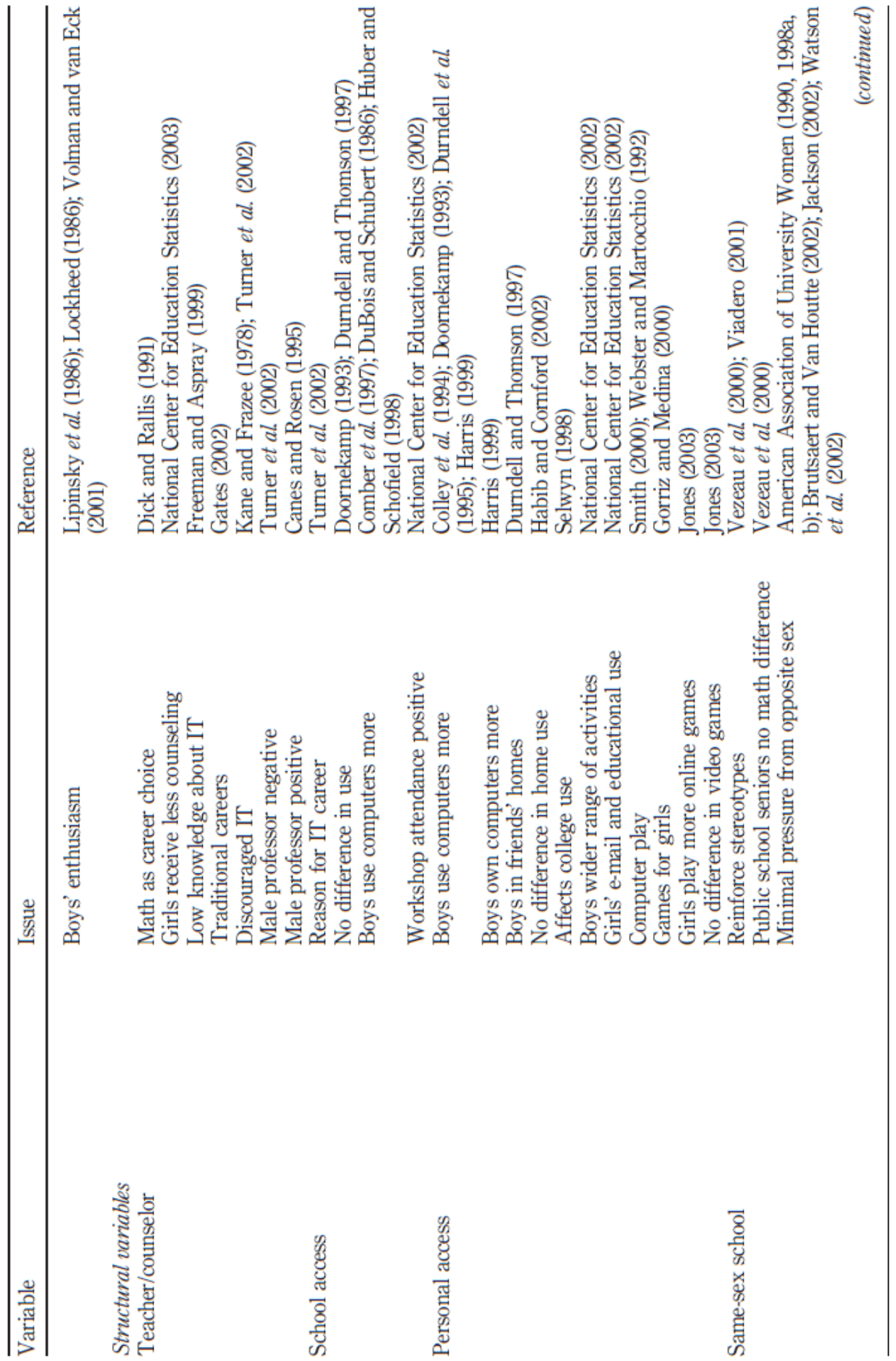

Information Technology \& People, Vol 18, No. 3 (2005): pg. 230-259. DOI. This article is (c) Emerald and permission has been granted for this version to appear in e-Publications@Marquette. Emerald does not grant permission for this article to be further copied/distributed or hosted elsewhere without the express permission from Emerald. 


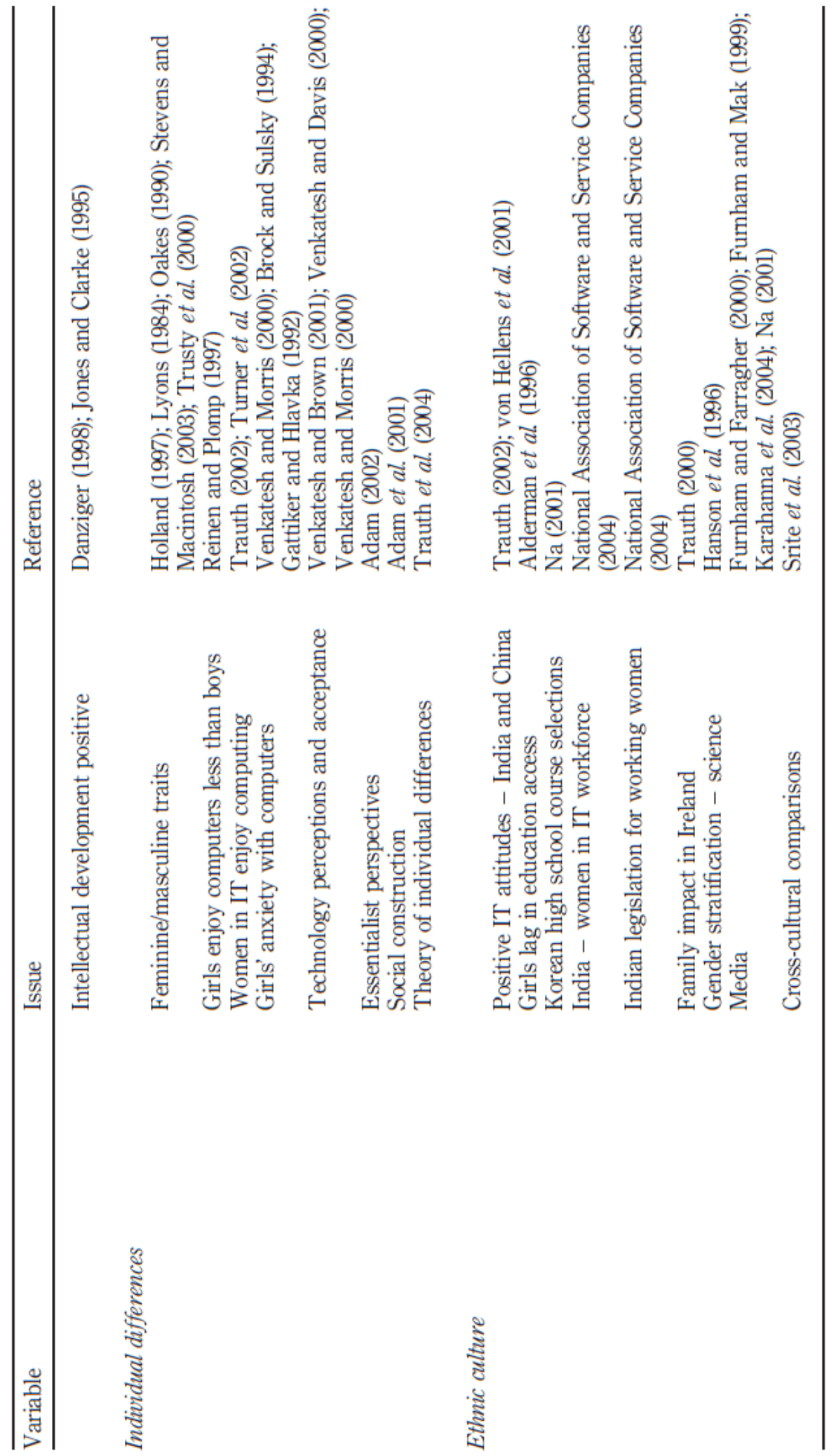

Information Technology \& People, Vol 18, No. 3 (2005): pg. 230-259. DOI. This article is (C) Emerald and permission has been granted for this version to appear in e-Publications@Marquette. Emerald does not grant permission for this article to be further copied/distributed or hosted elsewhere without the express permission from Emerald. 
Table II: Survey Instruments Adaptable to Girls' Career Choice

Model

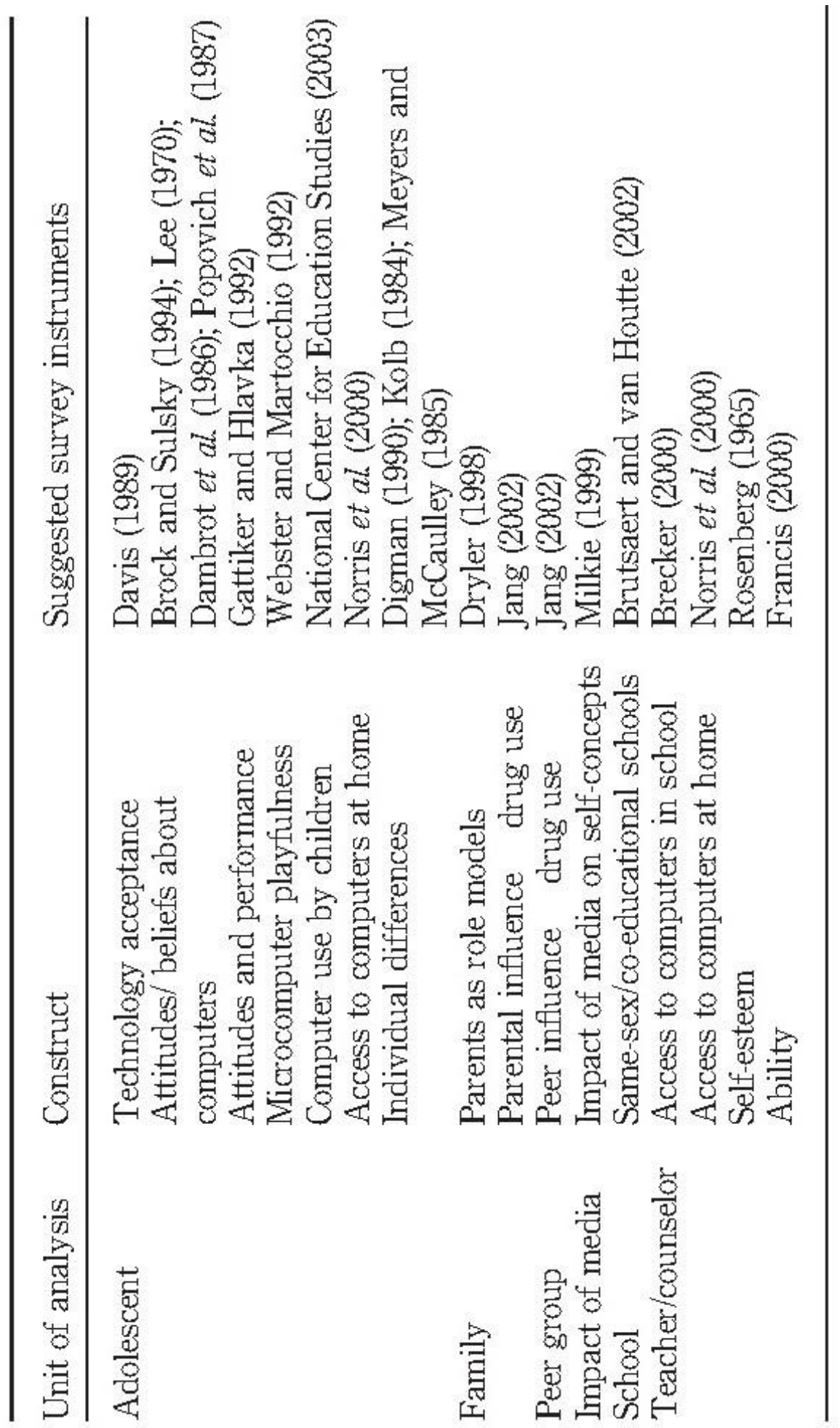

Information Technology \& People, Vol 18, No. 3 (2005): pg. 230-259. DOI. This article is @ Emerald and permission has been granted for this version to appear in e-Publications@Marquette. Emerald does not grant permission for this article to be further copied/distributed or hosted elsewhere without the express permission from Emerald. 